\title{
Evaluation of aerosol iron solubility over Australian coastal regions based on inverse modeling: implications of bushfires on bioaccessible iron concentrations in the Southern Hemisphere
}

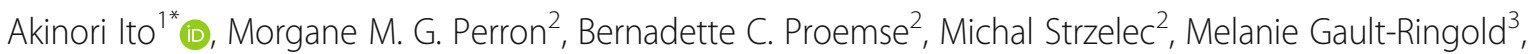 \\ Philip W. Boyd ${ }^{2,3}$ and Andrew R. Bowie ${ }^{2,3}$
}

\begin{abstract}
Mineral dust is the major source of external micro-nutrients such as iron (Fe) to the open ocean. However, large uncertainties in model estimates of Fe emissions and aerosol-bearing Fe solubility (i.e., the ratio of labile $\mathrm{Fe}\left(\mathrm{L}_{\mathrm{Fe}}\right)$ to total Fe $\left(T_{F e}\right)$ ) in the Southern Hemisphere $(\mathrm{SH})$ hampered accurate estimates of atmospheric delivery of bioavailable Fe to the Southern Ocean. This study applied an inverse modeling technique to a global aerosol chemistry transport model (IMPACT) in order to optimize predictions of mineral aerosol Fe concentrations based on recent observational data over Australian coastal regions $\left(110^{\circ} \mathrm{E}-160^{\circ} \mathrm{E}\right.$ and $\left.10^{\circ} \mathrm{S}-41^{\circ} \mathrm{S}\right)$. The optimized (a posteriori) model did not only better capture aerosol $\mathrm{T}_{\mathrm{Fe}}$ concentrations downwind from Australian dust outbreak but also successfully reproduced enhanced Fe solubility $(7.8 \pm 8.4 \%)$ and resulted in much better agreement of $\mathrm{L}_{\mathrm{Fe}}$ concentrations with the field measurements $\left(1.4 \pm 1.5\right.$ vs. $\left.1.4 \pm 2.3 \mathrm{ng} \mathrm{Fe} \mathrm{m}^{-3}\right)$. The a posteriori model estimates suggested that bushfires contributed a large fraction of $L_{F e}$ concentrations in aerosols, although substantial contribution from missing sources (e.g., coal mining activities, volcanic eruption, and secondary formation) was still inferred. These findings may have important implications for the projection of future micro-nutrient supply to the oceans as increasing frequency and intensity of open biomass burning are projected in the $\mathrm{SH}$.
\end{abstract}

Keywords: Mineral dust, Bushfire, Coal mine, Climate change, Bioaccessible iron, Labile iron

\section{Introduction}

Atmospheric deposition has been widely recognized as one of the major pathways for delivering essential micro-nutrients such as iron (Fe) to the open ocean (Fung et al. 2000; Jickells et al. 2005; Mahowald et al. 2005). Such external supply of Fe is particularly important in high-nutrient low-chlorophyll (HNLC) oceanic regions where even a small addition of this limiting

\footnotetext{
* Correspondence: akinorii@jamstec.go.jp

'Yokohama Institute for Earth Sciences, JAMSTEC, Yokohama, Kanagawa 236-0001, Japan

Full list of author information is available at the end of the article
}

nutrient can trigger disproportionately large phytoplankton blooms and therefore influence the export of organic materials to deep oceanic layers (Martin et al. 1988; Boyd et al. 2000, 2007). The Southern Ocean (SO) is the largest HNLC region of the globe and receives multiple sources of external $\mathrm{Fe}$, which show different temporal signatures and spatial gradients (de Baar et al. 1995; Mackie et al. 2008; Boyd and Ellwood 2010). The SO hosts a variety of distinct regional oceanic ecosystems characterized by unique physical and biological properties as well as different dominant processes of Fe supply (Boyd and Ellwood 2010). Therefore, large variabilities in

\section{Springer Open}

( ) The Author(s). 2020 Open Access This article is licensed under a Creative Commons Attribution 4.0 International License, which permits use, sharing, adaptation, distribution and reproduction in any medium or format, as long as you give appropriate credit to the original author(s) and the source, provide a link to the Creative Commons licence, and indicate if changes were made. The images or other third party material in this article are included in the article's Creative Commons licence, unless indicated otherwise in a credit line to the material. If material is not included in the article's Creative Commons licence and your intended use is not permitted by statutory regulation or exceeds the permitted use, you will need to obtain permission directly from the copyright holder. To view a copy of this licence, visit http://creativecommons.org/licenses/by/4.0/. 
the input of bioavailable $\mathrm{Fe}$ should be considered for predicting the response of $\mathrm{SO}$ marine ecosystems to $\mathrm{Fe}$ fertilization in ocean biogeochemistry models (Tagliabue et al. 2017). The term of "labile" $\mathrm{Fe}\left(\mathrm{L}_{\mathrm{Fe}}\right)$ is operationally defined as the fraction of aerosol Fe that can be leached from the particulate phase in the sum of the ultra-high purity water (UHPW) and the ammonium acetate (AA) leaches (Perron et al. 2020a). The operational definition of $\mathrm{L}_{\mathrm{Fe}}$ could be applied to measurements of both the deliquesced aerosol solution and seawater. To clarify the differences of chemical and physical forms in between aerosol water and seawater, "bioaccessible" Fe in aerosol water is defined as potentially "bioavailable" forms of Fe in seawater (Meskhidze et al. 2019). To avoid any confusion in comparing model estimates to observations in this study, we consider $\mathrm{L}_{\mathrm{Fe}}$ as bioaccessible Fe (Myriokefalitakis et al. 2018; Ito et al. 2019; Perron et al. 2020a).

A few land masses exist in south of the Equator to act as sources of $\mathrm{Fe}$ to the atmosphere, compared to the Northern Hemisphere (NH). Aerosols emitted from land masses can travel thousands of kilometers over periods of more than 2 weeks before settling to the seawater surface in remote parts of the ocean (Wagener et al. 2008). Such long-range atmospheric transport over the ocean leads to substantial atmospheric mixing between airmasses of various origins (Sholkovitz et al. 2012). Major sources of Fe over the SO include clay and silt soils entrained into the atmosphere due to the impacts of saltating particles on bare soil surface and due to pyroconvection from vegetated lands in the Southern Hemisphere $(\mathrm{SH})$ during dust and fire events, respectively (Mahowald et al. 2009; Neff et al. 2015: Ito and Kok 2017). Recently, there has been increasing attention paid to Fe-containing aerosols from underrepresented anthropogenic sources such as heavy industries and deforestation in the SH (Mahowald et al. 2018; Matsui et al. 2018; Ito et al. 2019; Conway et al. 2019). Such pyrogenic sources can enhance the global carbon export more efficiently than lithogenic Fe sources via the marine biological pump (Hamilton et al. 2020; Ito et al. 2020).

Global carbon emission fluxes from open biomass burning (BB) have mostly been estimated using satellite remote sensing (e.g., Hoelzemann et al. 2004; Ito and Penner 2004; van der Werf et al. 2017), which provides long-term observations with high-spatial resolution. Previous studies have reported large uncertainties associated with the satellite observations of open fires and with the modeling methods used to calculate the emissions fluxes from the observational data, and thus often applied a scaling factor to the particulate emissions from BB (Ito and Penner 2005; Zhang et al. 2005; Reddington et al. 2016). Indeed, the comparison of six global biomass burning emission datasets showed a large variation for Australian fire emissions between different data
(Pan et al. 2020). Additionally, there are large uncertainties in the $\mathrm{Fe}$ solubility (i.e., the ratio of $\mathrm{L}_{\mathrm{Fe}}$ to total $\mathrm{Fe}, \mathrm{T}_{\mathrm{Fe}}$ ) estimates for $\mathrm{BB}$ between different models (Myriokefalitakis et al. 2018; Ito et al. 2019). Moreover, model simulations on the oceanic response of atmospheric $\mathrm{L}_{\mathrm{Fe}}$ have recently raised increasing awareness on the potential role of $\mathrm{BB}$ in delivering $\mathrm{L}_{\mathrm{Fe}}$ to the SO (Hamilton et al. 2020; Ito et al. 2020).

The solubility of aeolian Fe will exert a key control on the impact of atmospheric supply on open ocean ecosystems (Baker and Croot 2010; Meskhidze et al. 2019). The solubility of aerosol $\mathrm{Fe}$ is initially characterized by the nature of the emission source (Schroth et al. 2009; Sholkovitz et al. 2012; Ito 2013). Subsequently, relatively insoluble Fe contained in aerosols is dynamically transformed into $\mathrm{L}_{\mathrm{Fe}}$ via physical and photochemical processing of aeolian particles during the atmospheric transport (Johnson and Meskhidze 2013; Myriokefalitakis et al. 2015; Ito and Shi 2016; Hamilton et al. 2019). Such processes include the preferential gravitational removal of larger mineral dust particles over smaller combustion aerosols during the atmospheric transport, which leads to smaller aerosol size particles but higher Fe solubilities away from emission sources (Sedwick et al. 2007; Luo et al. 2008; Hsu et al. 2010; Baker et al. 2016).

Atmospheric measurements of trace metal concentrations over the SO are sparse due to the technical and financial issues associated with long oceanographic research cruises in remote areas, and the scarcity of islands which are mostly inhospitable and difficult to access (Heimburger et al. 2013; Winton et al. 2015). Consequently, a small number of available field observations currently limit our understanding of the key factors controlling atmospheric $\mathrm{L}_{\mathrm{Fe}}$ concentration in aerosols over this region (Grand et al. 2015). In that regard, modeling studies are often used to extrapolate limited observational data both in space and time (Mahowald et al. 2009). Models are also used to project past and future changes in atmospheric $\mathrm{L}_{\mathrm{Fe}}$ deposition fluxes resulting from large-scale shifts in weather conditions such as those associated with El Niño Southern Oscillation (ENSO) or glacial/interglacial cycles (Mahowald et al. 2018). Moreover, model sensitivity studies (i.e., magnitude of the model response to each parameter investigated) can shed some light on possible key processes that warrant further investigation ( $\mathrm{Li}$ et al. 2008).

State-of-the-art global models are continuously adapted and implemented using new knowledge and observations from field and laboratory studies (Myriokefalitakis et al. 2018; Ito et al. 2019). Mineral dust emissions are typically scaled to match filed observations of aerosol optical properties, mass concentrations, and deposition fluxes (Ginoux et al. 2001; Huneeus et al. 2011; Adebiyi et al. 2020). However, dust events in the $\mathrm{SH}$ are sporadic and thus dust 
emission fluxes are not well constrained by the available observations. A recent inter-comparison study of aerosol $\mathrm{Fe}$ chemistry models under the joint Group of Experts on the Scientific Aspects of Marine Environmental Protection (GESAMP) revealed large disparities in the magnitudes of aerosol Fe emissions and the solubilities predicted across four models (Myriokefalitakis et al. 2018; Ito et al. 2019). Such discrepancies stem from intrinsic differences in the parametrization of aerosol Fe emissions, source-dependent initial solubilities, and the level of complexity chosen to represent atmospheric processes of Fe chemistry and deposition. Indeed, large uncertainties remain in model representations of $\mathrm{Fe}$ emission to the atmosphere and its subsequent chemistry and deposition to the ocean, particularly south of the Equator. The GESAMP study highlighted the necessity to improve our understanding of the key parameters controlling the atmospheric Fe cycle, which requires additional field observations and laboratory experiments to validate model predictions (Myriokefalitakis et al. 2018; Ito et al. 2019).

Here, a recent and extensive dataset gathering aerosol Fe measurements across the $70^{\circ} \mathrm{E}-150^{\circ} \mathrm{E}$ and $10^{\circ} \mathrm{S}-70^{\circ} \mathrm{S}$ sector of the SH (Perron et al. 2020b; Perron et al. pers. com.) was used to evaluate and improve the processbased understanding of enhanced aerosol Fe solubility in the Integrated Massively Parallel Atmospheric Chemical Transport (IMPACT) model (Ito et al. 2020 and references therein). This study presents the optimization of aerosol Fe concentration in the model to better reproduce field observations on regional scales. Subsequently, optimal model estimates of aerosol $\mathrm{L}_{\mathrm{Fe}}$ source apportionment are qualitatively compared to measurementbased estimates of enrichment factor (EF) (Perron et al. 2020b). Enrichment factors are defined as the mass ratios of total $\mathrm{Fe}$, lead $(\mathrm{Pb})$, and vanadium $(\mathrm{V})$ to Aluminum ( $\mathrm{Al})$ measured in aerosol samples divided by the same ratios measured in the averaged upper continental crust (McLennan 2001).

\section{Material and methods}

\section{Aerosol chemistry transport model}

The aerosol chemistry transport model used in this study was a coupled gas-phase (Ito et al. 2007) and aqueous-phase chemistry version (Liu et al. 2005; Lin et al. 2014) of the IMPACT model (Ito et al. 2020 and references therein). Simulations were performed for the period extending from 2016 to 2018, using a horizontal resolution of $2.0^{\circ} \times 2.5^{\circ}$ and 59 vertical layers. The model used the Modern Era Retrospective analysis for Research and Applications 2 (MERRA-2) reanalysis meteorological data from the National Aeronautics and Space Administration (NASA) Global Modeling and Assimilation Office (GMAO) (Gelaro et al. 2017).
The model simulated the emissions, chemistry, transport, and deposition of major aerosol species, including black carbon (BC), particulate organic matter (POM), mineral dust, sulfate, nitrate, ammonium, and sea spray aerosols, and their precursor gases (Rotman et al. 2004; Ito et al. 2015). Atmospheric processing of Fe-laden aerosols during atmospheric transport were projected for four distinct aerosol size bins $(0.1-1.26 \mu \mathrm{m}, 1.26-2.5$ $\mu \mathrm{m}, 2.5-5 \mu \mathrm{m}$, and 5-20 $\mu \mathrm{m}$ of diameter) (Ito and Feng 2010; Ito 2015). Dust emissions were dynamically simulated using a physically-based emission scheme (Kok et al. 2014; Ito and Kok 2017) with the soil mineralogical map (Journet et al. 2014). The global scaling factor of dust emission was determined to achieve best agreement with aerosol optical depth (AOD) measurements near the dust source regions from AErosol RObotic NETwork (AERONET) (Kok et al. 2014; Ito and Kok 2017). This procedure resulted in global (Australian) dust emissions of $4626 \mathrm{Tg} \mathrm{a}^{-1}\left(233 \mathrm{Tg} \mathrm{a}^{-1}\right)$ in 2016 and $4751 \mathrm{Tg} \mathrm{a}^{-1}$ $\left(408 \mathrm{Tg} \mathrm{a}^{-1}\right.$ ) in 2017, respectively. On the other hand, combustion emission fluxes were prescribed by the monthly estimates for each source sector (energy, industry, iron and steel smelting process, residential combustion, waste burning, and shipping) (Hoesly et al. 2018; Ito et al. 2018). The daily estimates for BB were based on a terrestrial biogeochemistry model in conjunction with satellite measurements, which showed good agreement with field observations of the fuel consumption for each biome on a global scale (Sato et al. 2007; Ito 2011; Ito et al. 2018).

The temporal variability of annual emissions of organic carbon (OC) from BB was compared to GFED4.1s over the period of 2004-2018 (van der Werf et al. 2017) (Fig. 1). Our global estimate of OC emission in 2008 was 17.3 $\mathrm{Tg} \mathrm{a}^{-1}$, which fell within the range of estimates in the six data sets (13.8-51.9 $\mathrm{Tg} \mathrm{a}^{-1}$ ) (Pan et al. 2020). Overall, our estimates of the interannual variability of global and Australian fire emissions were similar to GFED4.1s, mainly because the GFED burned area data set and compiled database of emission factor were used for both the estimates (van der Werf et al. 2017; Ito et al. 2018).

To improve the accuracy of our simulations of bioaccessible Fe deposition fluxes to the SO, we made several upgrades to the online emission schemes from the climatological emission database. The biogenic emissions of aerosols and the precursor gases from the sea surface were online calculated for the primary POM (Gantt et al. 2012), dimethylsulfide (DMS) (Keller et al. 2014), and isoprene (Hackenberg et al. 2017), which contributed to the formation of oxalate. Particle emission factors of oxalate were used to estimate the oxalate emissions for BB aerosols (Ferek et al. 1998). In addition to the primary sources, the oxalate was secondarily 


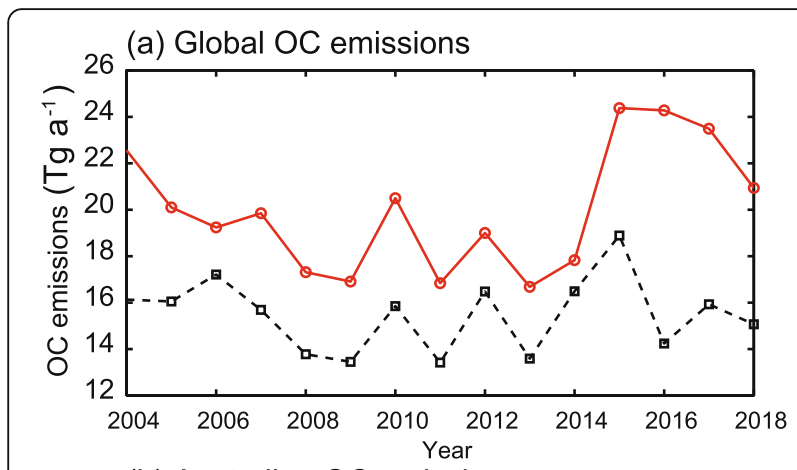

(b) Australian OC emissions

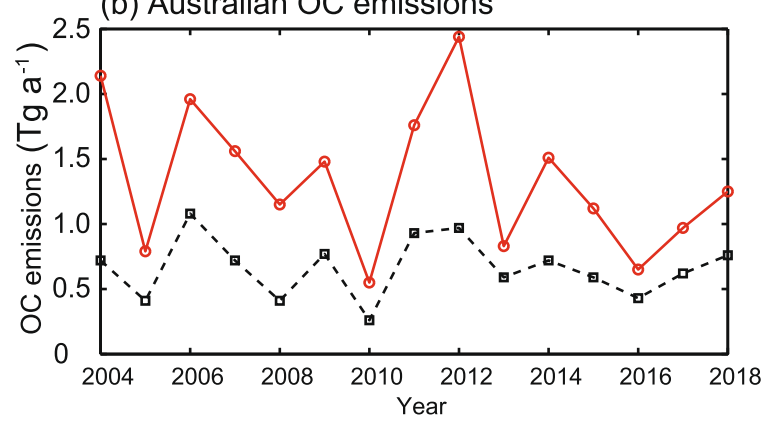

Fig. 1 Comparison of inter-annual variation in (a) global and (b) Australian organic carbon (OC) emissions $\left(\mathrm{Tg} \mathrm{a}^{-1}\right)$ from biomass burning in this work (red lines with circle symbols) to GFED4.1s (dashed black lines with square symbols)

formed in cloud water but was quickly consumed in Fecontaining aerosols due to photolysis of the Fe-oxalate complex in aqueous chemistry (Lin et al. 2014; Ito 2015). The transport and deposition of BC in the model was used to trace the fate of pyrogenic Fe particles of sub-micron size in the atmosphere (Luo et al. 2008; Ito and Feng 2010). The particle size distributions of BC derived from bushfires was described in Liu et al. (2005). Transformation of relatively insoluble Fe into $\mathrm{L}_{\mathrm{Fe}}$ following proton-promoted, oxalate-promoted, and photoreductive dissolution processes was simulated according to each aerosol Fe size bin for mineral dust and combustion aerosols (Ito 2015: Ito and Shi 2016).

\section{Aerosol dataset}

Measurements of aerosol Fe concentration and solubility used in this study resulted from an extensive ship-board atmospheric sampling effort undertaken between the years 2016 and 2018 in five distinct marine regions around Australia (North West Marine Region (NWMR), North Marine Region (NMR), Coral Sea Marine Region (CSMR), Temperate East Marine Region (TEMR), and South West Marine Region (SWMR)), and two regions around the Heard Islands and McDonald Islands (HIMI), which included an international study of the marine biogeochemical cycles of trace elements and their isotopes (GEOTRACES) section GIpr05, and along the $140^{\circ} \mathrm{E}$ meridional transect (SR3), which was a part of GEOTRACES section GS01. Perron et al. (2020b) in their supplementary material Table S1 reported key information related to aerosols collected over Australian marine regions including geographical coordinates, aerosol sample collection dates, and locations (mid-point latitude and longitude along the sampling track) as well as laboratory measurements of $\mathrm{T}_{\mathrm{Fe}}$ and $\mathrm{L}_{\mathrm{Fe}}$ concentrations in aerosols.

Aerosol sampling and laboratory processing were described in details in Perron et al. (2020a). Sampling and laboratory work were undertaken following GEOTRACES trace metal clean procedures (Cutter et al. 2017), including sample processing in a positive-pressured clean laboratory wearing clean garments and using either ultrahigh purity commercially-available (Baseline grade, Seastar chemicals) or in-house distilled acids.

Briefly, aerosol collection was undertaken by placing Whatman 41 (W41) cellulose filters inside pre-cleaned Savillex filter holders housed in a high-efficiency particulate air (HEPA)-filtered portable laminar flow hood. Air was pumped from $18 \mathrm{~m}$ above the sea level through successive polished stainless-steel and anti-static conductive tubing to prevent particle loss inside the tube walls. The sampling manifold pumps were automatically activated for a wind sector between $90^{\circ}$ and $270^{\circ}$ facing the ship and a wind speed within a 5-80 knots range according to the ship's meteorological data, in order to avoid direct sampling of the ship's exhaust. A volume of air filtered exceeding $20 \mathrm{~m}^{3}$ over coastal waters and $50 \mathrm{~m}^{3}$ over the remote ocean was used as minimum thresholds to define the time of sample change over, ensuring sufficient material on the filter to overcome the filter blank. Upon collection, samples were stored frozen in double sealed bags until processing in the shore-based laboratory. It should be noted that the $20 \mu \mathrm{m}$ nominal pore size of the W41 cellulose filter is not representative of the effective filter retention capacity as the layering of fibers within the filter paper retains most $<20 \mu \mathrm{m}$ particles by interception, impaction or diffusion (Lindsley et al. 2016). We therefore assume that field measurements (Perron et al. 2020b) captured all the above-mentioned size bins, which corresponded to the sum of four size bins included in the IMPACT model.

Aerosol samples were processed through a 3-step leaching experiment using an instantaneous flowthrough leach of UHPW followed by a batch extraction in AA (1.1 M, pH 4.7) and a final $\mathrm{HF} / \mathrm{HNO}_{3}$ overnight digestion at $120{ }^{\circ} \mathrm{C}$. The $\mathrm{T}_{\mathrm{Fe}}$ concentration in aerosols was defined as the sum of Fe concentrations measured in the three leaches and expressed in nanogram of $\mathrm{Fe}$ per cubic meter of air filtered $\left(\mathrm{ng} \mathrm{m}^{-3}\right)$. The $\mathrm{L}_{\mathrm{Fe}}$ concentrations were obtained from $\mathrm{Fe}$ measured in the sum of the UHPW and the AA leaches. Based on the analysis of 
three replicate samples, relative standard deviations (accounting for uncertainty of the sampling method and the leaching protocol) were estimated for $\mathrm{T}_{\mathrm{Fe}}(11.7 \%)$ and $\mathrm{L}_{\mathrm{Fe}}(10.3 \%)$ concentrations (Perron et al. 2020a).

\section{Sensitivity experiments}

The IMPACT model representation of aerosol Fe was evaluated using field measurements of $\mathrm{T}_{\mathrm{Fe}}$ and $\mathrm{L}_{\mathrm{Fe}}$ concentrations in the $70^{\circ} \mathrm{E}-150^{\circ} \mathrm{E}$ and $10^{\circ} \mathrm{S}-70^{\circ} \mathrm{S}$ sector of the SH (Perron et al. 2020b; Perron et al. pers. com.). In addition to the a priori simulation (Experiment 1), three experiments were performed with different assumptions on the aerosol Fe emissions for Australian mineral dust (Experiment 2), and on the solubility of $\mathrm{Fe}$ in $\mathrm{BB}$ (Experiment 3) and in mineral dust (Experiment 4) aerosols (Table 1). Inverse modeling techniques have been widely applied to the optimization of emission estimates (Enting et al. 1995). The synthesis process sought to estimate the strength, $\sigma_{\mu}$, of total $M$ source/sink processes by comparing concentrations reported in field observation, $c$, to modeled responses, $T_{\mu}$ calculated by the forward model, based on the assumption that

$$
c=\sum_{\mu=1}^{M} T_{\mu} \sigma_{\mu}+(\text { observational noise })
$$

Here, the forward model was first simulated to derive atmospheric concentration of mineral dust from Australia which was used as "tagged" tracer considering zero emission of mineral dust from other regions for the four aerosol size bins. The enrichment factor for $\mathrm{Fe}$ $\left(\mathrm{EF}_{\mathrm{Fe}}\right)$ suggested that aerosol $\mathrm{Fe}$ mostly displayed a crustal origin as the median $\mathrm{EF}_{\mathrm{Fe}}$ of 2.5 likely reflected the well-described $\mathrm{Fe}$ enrichment in soil from the outback Australia (Perron et al. 2020b) (Fig. 2a). At the same time, the a priori model outputs suggested minor contribution of non-Australian mineral dust to the sum of $\mathrm{T}_{\mathrm{Fe}}$ concentrations originated from all the dust source regions near the Australian continent for the five regions (Fig. 2b). Thus, inverse model calculations were performed to adjust the regional scaling constant for mineral dust emission fluxes from Australia $(\mu=M)$, in order to maximize the agreement between $\mathrm{T}_{\mathrm{Fe}}$ from the model and from field measurements near the Australian continent for the five regions. The regional scaling constant was perturbed to minimize the cost function, $\theta$, in order to optimize aerosol Fe source strength from Australian mineral dust at total $N$ data points and observational $j$ locations:

$$
\theta=\sum_{j=1}^{N}\left(c_{j}-\sum_{\mu=1}^{M-1} T_{j \mu}-\sum_{\mu=M}^{M} T_{j \mu} \sigma\right)^{2} / u_{j}^{2}
$$

where $u_{j}$ was the standard deviation of the observational noise. In this study, the a posteriori estimate of aerosol Fe emission from Australian dust sources was undertaken using a regional scaling factor of 0.0106 (Experiment 2, Experiment 3, and Experiment 4). When we applied this scaling factor to Australian dust emissions, the agreement with the AERONET AOD on a global scale was slightly improved for the correlation coefficients (root mean square errors) from $0.77(0.11)$ to 0.78 (0.10). The scaling factor, however, ineluctably comprises uncertainty on soil mineralogy and Fe content partly due to the limited number of observations available over most arid and semi-arid regions. Accordingly, the reduction of $\mathrm{Fe}$ emissions from mineral sources in the a posteriori model moderated the overall impact of the uncertainty in the Fe content on the estimate of bulk aerosol Fe solubility in the model.

The source apportionment of $\mathrm{L}_{\mathrm{Fe}}$ is extremely sensitive to Fe solubility in BB over the SH (Ito 2012). To quantify the effect of spatially varying solubility relative to constant solubility, Experiment 3 adjusted the uniform Fe solubility (22\%) for BB aerosols only to maximize agreement with $\mathrm{L}_{\mathrm{Fe}}$ measurements near the Australian continent due to the optimization through the inverse method. The sensitivity of the IMPACT model to the initial Fe solubility in mineral dust was previously shown on a global scale (Ito and Shi 2016). The IMPACT model assumed lower initial Fe solubility at emission for mineral dust $(0.1 \%)$ than that $(0.3 \%)$ derived from Australian dust (Mackie et al. 2005). To show the sensitivity on simulated Fe solubility from the atmospheric processing of mineral dust, the initial solubility of $0.3 \%$ for dust was prescribed at emissions with no atmospheric processing of dust only (Experiment 4).

Table 1 Summary of sensitivity simulations performed for Fe emission for Australian mineral dust, Fe solubility for BB aerosols, and Fe solubility for mineral dust

\begin{tabular}{llll}
\hline Experiment & Fe emission in dust & Fe solubility in BB & Initial dust Fe solubility \\
\hline Experiment 1 & A priori model & Online calculation & $0.1 \%$ \\
Experiment 2 & A posteriori model & Online calculation & $0.1 \%$ \\
Experiment 3 & A posteriori model & A posteriori estimate (22\%) & $0.1 \%$ \\
Experiment 4 & A posteriori model & Online calculation & $0.3 \%$ \\
\hline
\end{tabular}




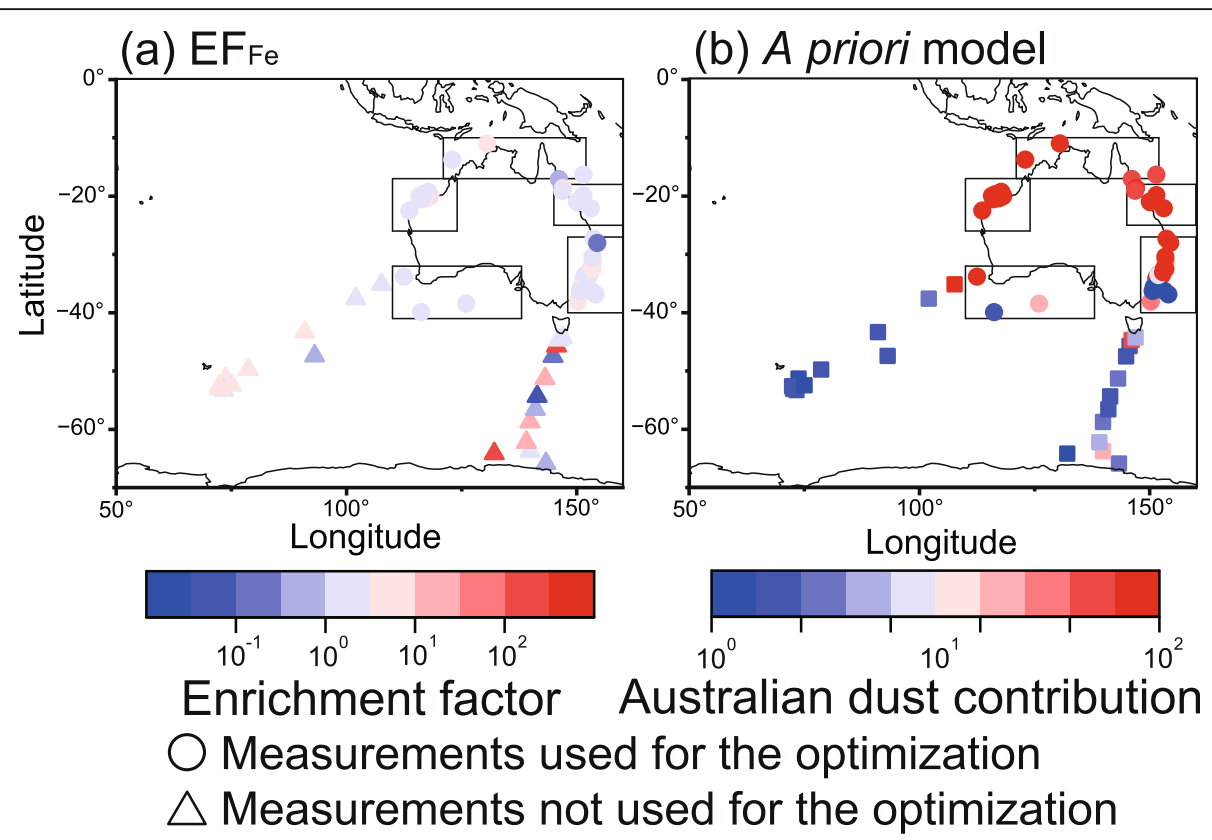

Fig. 2 Variability in $(\mathbf{a})$ enrichment factor in $\mathrm{Fe}\left(\mathrm{EF}_{\mathrm{Fe}}\right)$ and $(\mathbf{b})$ a priori model contribution of Australian dust sources to global dust $\mathrm{T}_{\mathrm{Fe}}(\%)$ in each sampled aerosol (or associated geographical grid cell)

The averages and standard deviations were calculated from the daily a priori and a posteriori model estimates along the cruise tracks during sampling periods and compared to field observations in each sub-region to highlight variability in the model representation of different aeolian Fe sources. The tagged tracers were also used to estimate the relative contribution from mineral dust, coal combustion, oil combustion, and biomass burning sources at each size bin. The modeled source apportionment of $\mathrm{T}_{\mathrm{Fe}}$ and $\mathrm{L}_{\mathrm{Fe}}$ was compared to the enrichment factors calculated using the field measurements (Perron et al. 2020b; Perron et al. personal comms.). Indeed, $\mathrm{Pb}$ and $\mathrm{V}$ are often enriched in anthropogenic aerosols from coal and oil combustion and thus can be used to relate changes in $\mathrm{L}_{\mathrm{Fe}}$ for each tagged tracer, respectively.

\section{Results and discussion}

\section{Comparison of $\mathrm{T}_{\mathrm{Fe}}$ and $\mathrm{L}_{\mathrm{Fe}}$ between model and} observational data

Estimates of $\mathrm{T}_{\mathrm{Fe}}$ and $\mathrm{L}_{\mathrm{Fe}}$ concentrations from the two simulations (Experiment 1 and Experiment 2) were displayed in Fig. 3 along with field observations for aerosol samples collected across the $70^{\circ} \mathrm{E}-150^{\circ} \mathrm{E}$ and $10^{\circ} \mathrm{S}-70^{\circ} \mathrm{S}$ sector of the $\mathrm{SH}$ (Table S1). The a priori IMPACT model overestimated the atmospheric $\mathrm{T}_{\mathrm{Fe}}$ concentrations and underestimated Fe solubilities (Table 2, Fig. 4). Indeed, aerosol $\mathrm{T}_{\mathrm{Fe}}$ (up to $9024 \mathrm{ng} \mathrm{m}^{-3}$ ) estimated by the a priori IMPACT model during dust events were a factor of 100 higher than field measurements of $\mathrm{T}_{\mathrm{Fe}}$ (up to 103 ng $\mathrm{m}^{-3}$ ). Moreover, the a priori model predictions often estimated Fe solubility below $2 \%$, as illustrated by the solid black line in Fig. 3, while field measurements reported values of Fe solubilities up to $100 \%$.

Much smaller discrepancies existed in both the mean and median values of $\mathrm{T}_{\mathrm{Fe}}$ and $\mathrm{L}_{\mathrm{Fe}}$ between the field observations and the a posteriori model estimates (Experiment 2, Experiment 3, and Experiment 4), compared to between the field observations and the a priori model (Experiment 1) (Table 2, Fig. 4). The better agreement of the median value rather than the mean value between Experiment 1 and the field observations suggested that the a priori model did not capture extremely high values during dust outbreak (Hamilton et al. 2019; Ito et al. 2019). On the other hand, the a posteriori IMPACT model output (Experiment 2) showed identical averaged $\mathrm{L}_{\mathrm{Fe}}$ to field observations $\left(1.4 \pm 1.5\right.$ vs. $1.4 \pm 2.3 \mathrm{ng} \mathrm{Fe} \mathrm{m}{ }^{-}$ $\left.{ }^{3}\right)$. The optimization of Fe solubility in aerosols originated from BB sources (Experiment 3) resulted in slightly smaller $\mathrm{L}_{\mathrm{Fe}}$ concentrations in aerosols $(0.8 \pm 0.9$

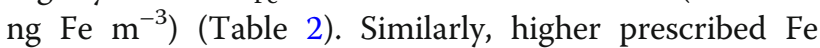
solubility in mineral dust aerosols with no atmospheric processing of dust only (Experiment 4) led to slightly lower $\mathrm{L}_{\mathrm{Fe}}$ concentrations $\left(1.1 \pm 1.2 \mathrm{ng} \mathrm{Fe} \mathrm{m}^{-3}\right.$ ) (Table 2). These results suggested that our conclusion was robust even if we applied the three-fold higher initial Fe solubility for mineral dust source (Mackie et al. 2005) with no atmospheric processing or if we adjusted the Fe solubility for BB. However, the scaling factor is extremely sensitive to sporadic dust outbreak and the intensity of dust 


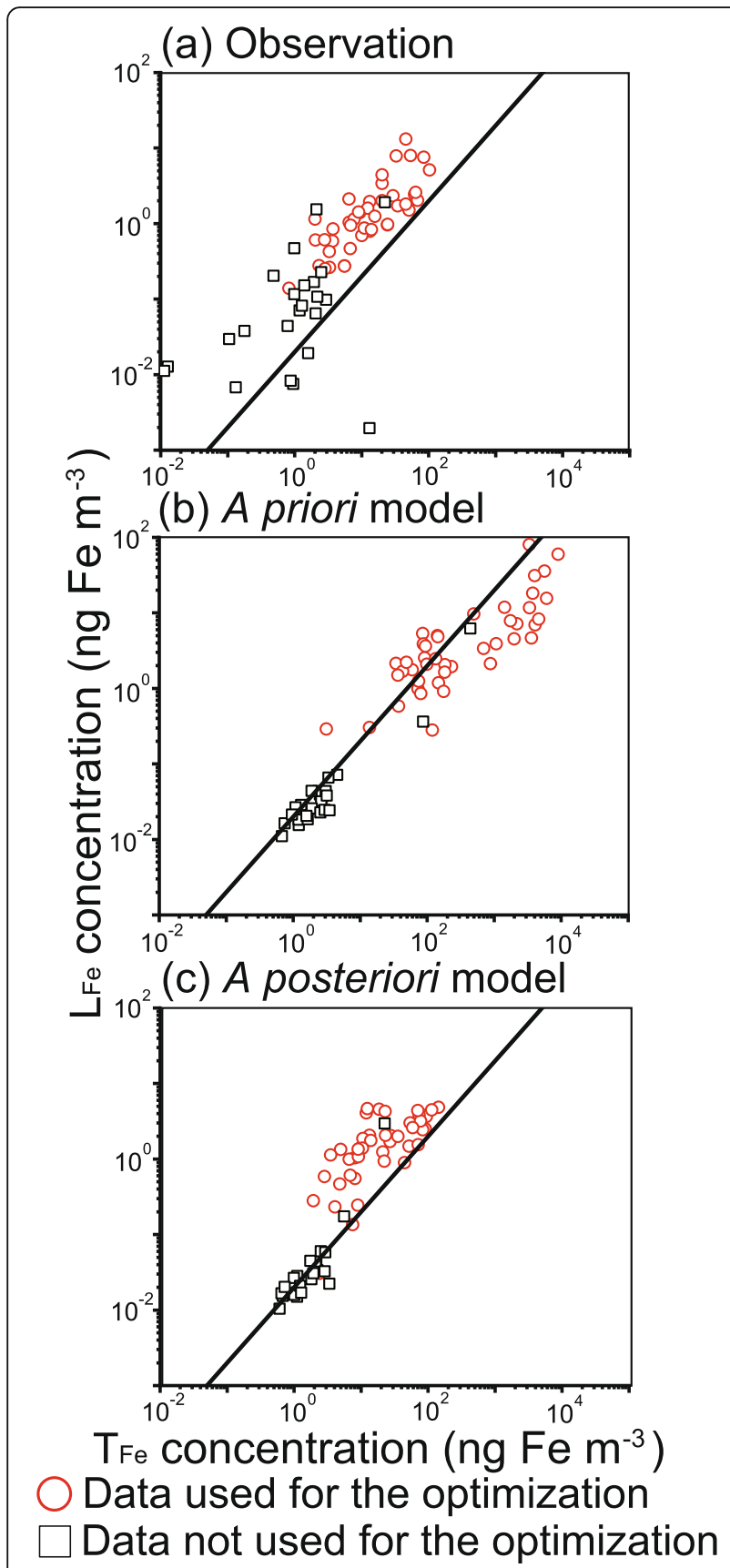

Fig. 3 Relationship between $T_{\mathrm{Fe}}$ and $\mathrm{L}_{\mathrm{Fe}}$ concentrations (ng Fe $\mathrm{m}^{-3}$ ) in aerosols for $\mathbf{a}$ observations, $\mathbf{b}$ a priori model estimates, and $\mathbf{c}$ a posteriori model estimates over the $70^{\circ} \mathrm{E}-150^{\circ} \mathrm{E}$ and $10^{\circ} \mathrm{S}-70^{\circ} \mathrm{S}$ sector of the $\mathrm{SH}$. The solid black line shows a linear trend with a constant Fe solubility of $2 \%$

emissions is different for different model inputs and parameters. Moreover, the optimized model did not capture the wide range of Fe solubilities reported by field observations over the remote ocean (black squares in Fig. 3) where low aerosol Fe concentration prevailed. Such tendency was reported in the GESAMP intercomparison study of four widely used atmospheric $\mathrm{Fe}$ chemistry models (including IMPACT), highlighting the need for better constraining key parameters controlling atmospheric Fe cycling including the magnitude of atmospheric emissions and the processes leading to enhanced aerosol Fe solubilities over the SO (Myriokefalitakis et al. 2018; Ito et al. 2019).

\section{Spatial distribution of $\mathrm{T}_{\mathrm{Fe}}$ concentration and Fe solubility in aerosols}

Averaged $\mathrm{T}_{\mathrm{Fe}}$ concentrations and Fe solubilities during the different sampling periods along the cruise tracks were estimated before (a priori) and after (a posteriori) model optimizations. The spatial distribution of $\mathrm{T}_{\mathrm{Fe}}$ and Fe solubility from the a priori and a posteriori model estimates was compared to field observation in Figs. 5 and 6, respectively. Comparison of the a priori and a posteriori estimates to observational data highlighted the magnitude of the improvements inferred by the optimization of the IMPACT model (Figs. 5 and 6).

The initial (a priori) estimates of $\mathrm{T}_{\mathrm{Fe}}$ in the model were significantly higher than the observations in the NWMR (Fig. 5). This region is located downwind from the northwestern Australian dust path (Bowler et al. 1976; Baddock et al. 2015), which suggested an exaggeration of dust emission from arid and semi-arid lands in the a priori model output. Such overestimates of Fe emission from Australian mineral dust suggested that the process-based models needed to consider the "history" of ground surface conditions explicitly (Prospero et al. 2002; Ishizuka et al. 2008; Jickells and Moore 2015). As the distances from mineral dust source regions increased, model overestimates of $\mathrm{T}_{\mathrm{Fe}}$ were reduced in the NMR, CSMR, TEMR, and SWMR (Fig. 5). The optimization of the IMPACT model using the inverse modeling technique led to significantly better agreement between $\mathrm{T}_{\mathrm{Fe}}$ from the a posteriori model output and from field observations in the NWMR, NMR, CSMR, TEMR, and SWMR. Conversely, the initial (a priori) model estimates of $\mathrm{T}_{\mathrm{Fe}}$ were in good agreement with the field observations in the HIMI and along the SR3. Minor changes in $\mathrm{T}_{\mathrm{Fe}}$ between the a priori and the a posteriori model outputs reflected the small contribution of Australian mineral dust to $\mathrm{T}_{\mathrm{Fe}}$ concentrations in these remote oceanic regions. Over the $\mathrm{SO}$, atmospheric $\mathrm{T}_{\mathrm{Fe}}$ could either be dominated by local emissions near Antarctica (Gao et al. 2013) or influenced by well-mixed aerosol sources during the long-range transport of the air masses.

The a priori model estimates of aerosol Fe solubility were up to 10 times lower than field measurements in the NWMR where $\mathrm{T}_{\mathrm{Fe}}$ from mineral dust sources was significantly overestimated (Fig. 6). The a priori model output also significantly underestimated aerosol Fe solubility over the other northern (NMR and CSMR) and 
Table 2 Averages and standard deviations of $\mathrm{T}_{\mathrm{Fe}}$ and $\mathrm{L}_{\mathrm{Fe}}$ concentrations (ng Fe $\mathrm{m}^{-3}$ ) and Fe solubility (\%) over the $70^{\circ} \mathrm{E}-150^{\circ} \mathrm{E}$ and $10^{\circ} \mathrm{S}-70^{\circ} \mathrm{S}$ oceanic sector of the $\mathrm{SH}$. The parenthesis represents the median and maximum

\begin{tabular}{llll}
\hline Data set & $\mathrm{T}_{\mathrm{Fe}}\left(\mathrm{ng} \mathrm{Fe} \mathrm{m}^{-3}\right)$ & $\mathrm{L}_{\mathrm{Fe}}\left(\mathrm{ng} \mathrm{Fe} \mathrm{m}^{-3}\right)$ & Fe solubility (\%) \\
\hline Measurement & $16 \pm 22(6.4,103)$ & $1.4 \pm 2.3(0.7,13)$ & $16 \pm 20(9.0,100)$ \\
Experiment 1 & $908 \pm 1788(86,9024)$ & $5.7 \pm 13(1.6,80)$ & $1.8 \pm 1.7(1.4,9.4)$ \\
Experiment 2 & $23 \pm 32(8.1,143)$ & $1.4 \pm 1.5(1.0,4.9)$ & $7.8 \pm 8.4(4.2,38)$ \\
Experiment 3 & $23 \pm 32(8.1,143)$ & $0.8 \pm 0.9(0.6,3.4)$ & $4.9 \pm 5.2(3.2,30)$ \\
Experiment 4 & $23 \pm 32(8.1,143)$ & $1.1 \pm 1.2(0.6,4.2)$ & $4.7 \pm 3.8(6.9,57)$ \\
\hline
\end{tabular}

southern (TEMR and SWMR) coastlines $(1.9 \pm 2.0 \%$ vs. $13 \pm 10 \%)$. Enhanced aerosol Fe solubility in the eastern marine regions of Australia has been attributed to large mass emissions of anthropogenic particles (Perron et al. 2020b; Strzelec et al. 2020). Indeed, a coating of pyrogenic Fe-containing aerosols with acidic species (e.g., sulphate) has been shown to release $\mathrm{L}_{\mathrm{Fe}}$ in the acidic deliquescent layer of aerosols and enhance Fe solubility in aerosols during the atmospheric transport ( $\mathrm{Li}$ et al. 2017; Ito et al. 2019). The a posteriori model output (Experiment 2) showed that the reduction in Fe emissions from Australian mineral dust in the model led to a significant increase in aerosol Fe solubility (compared to the a priori model output), similar to that obtained from the observational data near the Australian continent. The a posteriori model output further indicated high $\mathrm{Fe}$ solubility in the NMR, which resulted in better agreement with the observational data. In the NMR region, devastating fires often occur during the austral dry season (Paton-Walsh et al. 2014; Winton et al. 2016; Mallet et al. 2017).

Atmospheric processing including acidic reactions and photoreduction likely influence the form of Fe minerals and oxidation state in mineral dust aerosols and contribute to increases in aerosol Fe solubility over the North Atlantic (Longo et al. 2016). In the $\mathrm{SH}$, emissions of acidic gases to the atmosphere are much smaller than in the $\mathrm{NH}$. We found that the a posteriori model could reproduce the high Fe solubility even when the atmospheric processing was not considered for mineral dust only (Experiment 4) (Table 2). This reflects the slower Fe dissolution rates for mineral dust during the shorter lifetime of aerosols, compared to combustion aerosols.

A previous study used observations of stable Fe isotopes to constrain a model representation of atmospheric $\mathrm{L}_{\mathrm{Fe}}$ over the North Atlantic downwind from the North African dust source region (Conway et al. 2019). Their results suggested that improvement of modeled $\mathrm{L}_{\mathrm{Fe}}$ deposition required both a reduction of the $\mathrm{L}_{\mathrm{Fe}}$ content in mineral dust and an increase in pyrogenic sources of $\mathrm{Fe}$ from anthropogenic activities. In our study, the single reduction of Fe emission for Australian mineral dust sources in the model led to enhanced aerosol Fe solubilities, which were in better agreement with the field observations. Since the magnitude of anthropogenic emissions of acidic gases and Fe-containing aerosols is substantially smaller across the $\mathrm{SH}$ compared to the $\mathrm{NH}$, our finding is likely to be relevant for the modeling over the SO.

\section{Aerosol Fe source apportionment in the eastern $\mathrm{SH}$}

The IMPACT model was used to infer dominant sources of $\mathrm{T}_{\mathrm{Fe}}$ and $\mathrm{L}_{\mathrm{Fe}}$ in distinct Australian coastal regions as well as over the SO (Table S2). Atmospheric tracers tagged with each source sector in the IMPACT model included dust, oil combustion, coal combustion, and BB. Results were shown in Table 3 for $\mathrm{T}_{\mathrm{Fe}}$ and Table 4 for $\mathrm{L}_{\mathrm{Fe}}$, respectively.

The a posteriori IMPACT model (Experiment 2) attributed between $57 \%$ and $99 \%$ of the atmospheric $\mathrm{T}_{\mathrm{Fe}}$ across the study region to dust sources (Table 3). This projection is consistent with conventional modeling studies reporting that dust is the dominant contributor to oceanic deposition of $\mathrm{T}_{\mathrm{Fe}}$ (Mahowald et al. 2009). Regionally, up to $92 \%, 93 \%$, and $99 \%$ of the atmospheric $\mathrm{T}_{\mathrm{Fe}}$ was attributed to Fe-laden mineral aerosol sources in the NWMR, the HIMI, and along the SR3, respectively. In the NWMR, aerosol Fe predominantly originated from arid and semi-arid regions via the North West dust path (Bowler et al. 1976; Baddock et al. 2015). A non-negligible influence from anthropogenic emissions was found in the TEMR where $23 \%$ of the atmospheric $\mathrm{T}_{\mathrm{Fe}}$ was attributed to coal and $2.9 \%$ to oil combustion sources. Natural and human-derived biomass burning was estimated to contribute $17 \%, 24 \%$, and $30 \%$ of the aeolian $\mathrm{T}_{\mathrm{Fe}}$ in the TEMR, CSMR, and NMR, respectively. Over the $\mathrm{SO}$, oil combustion was pointed out as minor sources of atmospheric $\mathrm{T}_{\mathrm{Fe}}$ both in the HIMI (1.0\%) and along the SR3 (0.9\%). Finally, minor contribution of $\mathrm{BB}$ over the SO (up to $5 \%$ ) was derived from long-range atmospheric transport of various airmass origins, which were emitted from vegetated lands thousands of kilometers west (upwind) of the sampled regions (Wagener et al. 2008).

While $\mathrm{T}_{\mathrm{Fe}}$ computed by the model was largely dominated by dust, the relative contribution of each of the four emission sources showed larger variabilities when considering $\mathrm{L}_{\mathrm{Fe}}$ (Table 4). Indeed, the a posteriori IMPA 

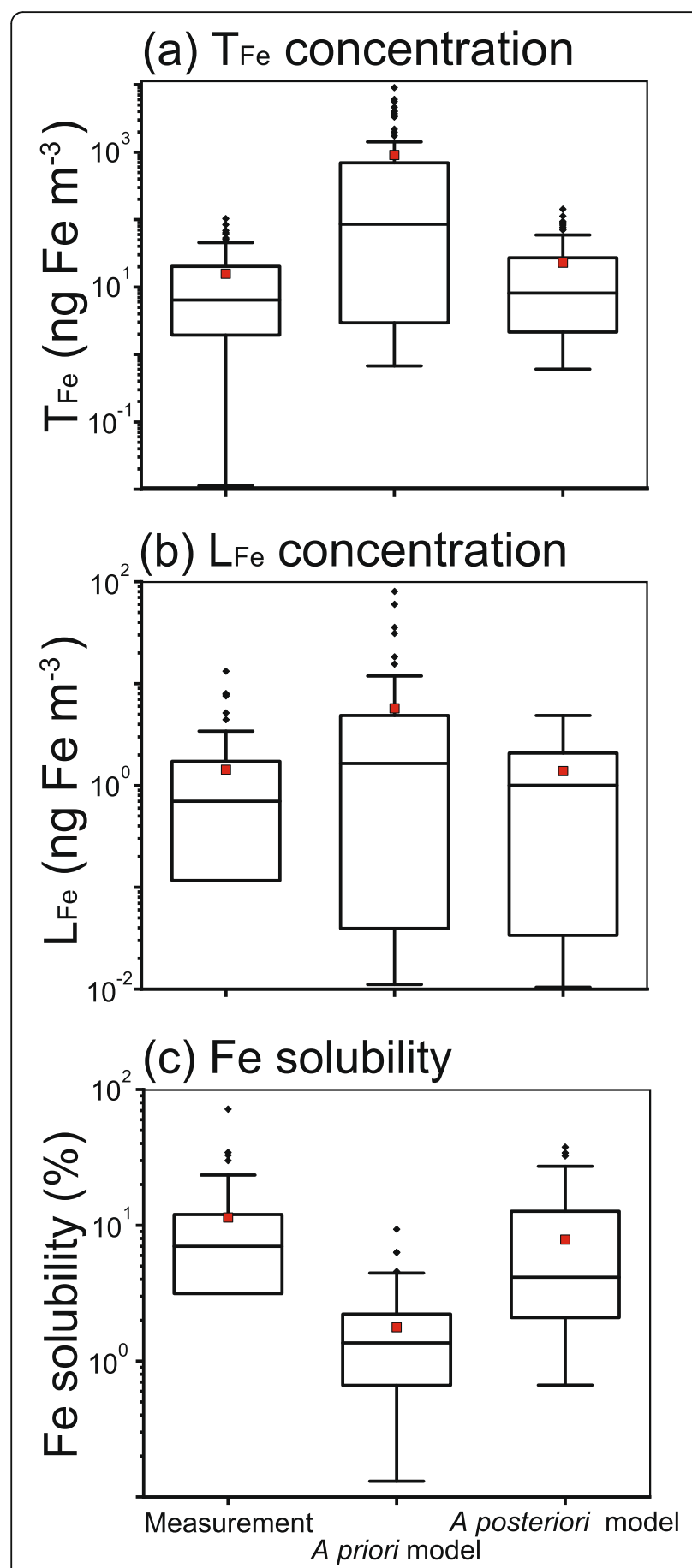

Fig. 4 Concentrations of $\mathbf{a} T_{\mathrm{Fe}}$ and $\mathbf{b} \mathrm{L}_{\mathrm{Fe}}$ concentrations (ng Fe $\mathrm{m}^{-3}$ ), and $\mathbf{c}$ Fe solubility (\%) for observations, a priori model estimates, and a posteriori model estimates over the $70^{\circ} \mathrm{E}-150^{\circ} \mathrm{E}$ and $10^{\circ} \mathrm{S}-70^{\circ} \mathrm{S}$ oceanic sector of the $\mathrm{SH}$. The red square symbol represents the mean. The solid line within the box mark shows the median. The boundaries of the box mark the 25th and 75th percentiles. The whiskers above and below the box indicate the $1.5 \times$ interquartile range, and the points indicate the outside of the range

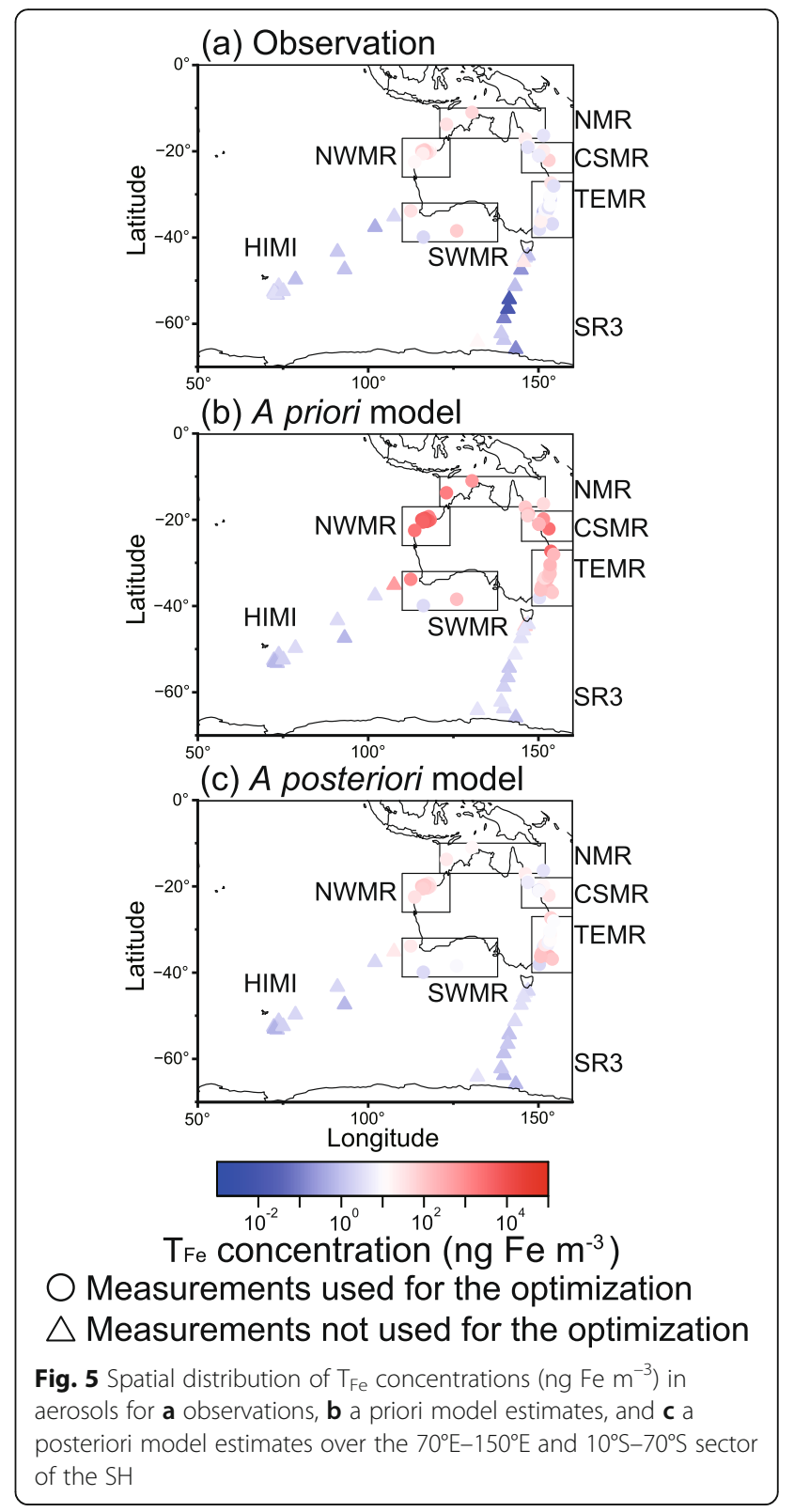

CT model only attributed between $12 \%$ and $58 \%$ of $\mathrm{L}_{\mathrm{Fe}}$ to the mineral dust around Australia (Table 4). Rather, aeolian $\mathrm{L}_{\mathrm{Fe}}$ over Australian coastal waters was largely associated with BB emissions (between $15 \%$ and $82 \%$ ). This apportionment is reasonably consistent with field studies emphasizing the importance of biomass burning emissions to the atmospheric burden near Australia (Winton et al. 2016; Mallet et al. 2017; Perron et al. 2020b). In the NMR, aerosols were collected simultaneously with the occurrence of a large fire event in northwestern Australia which likely influenced atmospheric $\mathrm{L}_{\mathrm{Fe}}$ source apportionment (82\%) estimated by the model (Perron et al. 2020b). 


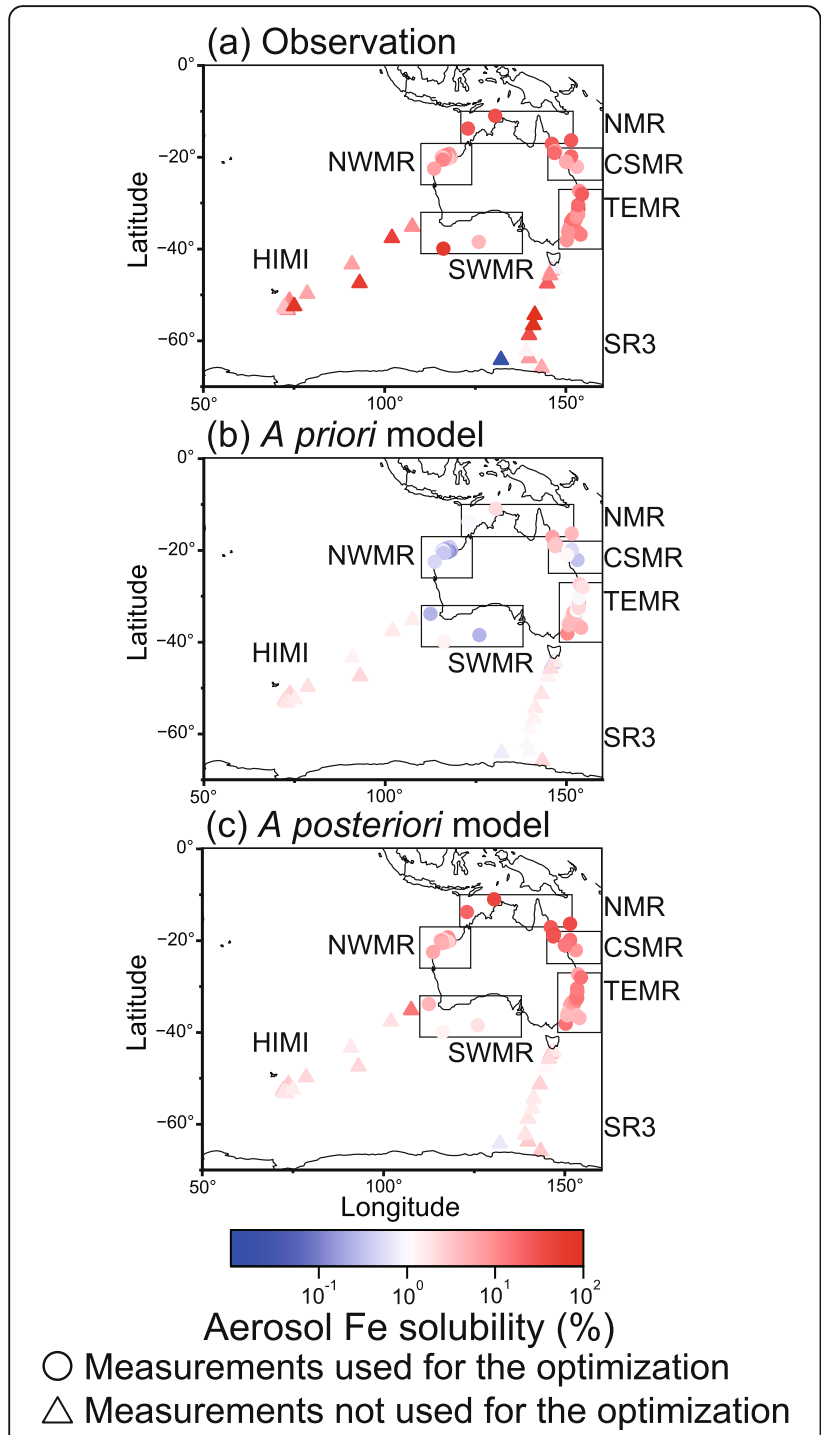

Fig. 6 Spatial distribution of aerosol Fe solubility (\%) for a observations, $\mathbf{b}$ a priori model estimates, and $\mathbf{c}$ a posteriori model estimates over the $70^{\circ} \mathrm{E}-150^{\circ} \mathrm{E}$ and $10^{\circ} \mathrm{S}-70^{\circ} \mathrm{S}$ sector of the $\mathrm{SH}$

The values of EF were calculated for each sample to discriminate $\mathrm{Fe}$ from anthropogenic pollution $\left(\mathrm{EF}_{\mathrm{Pb}}\right.$ and $E F_{V}$ for coal combustion and oil combustion, respectively) over natural dust $\left(\mathrm{EF}_{\mathrm{Fe}}\right)$. The relative contribution of coal and oil combustion sources to $\mathrm{L}_{\mathrm{Fe}}$ as predicted by the a posteriori IMPACT model was reasonably consistent with reported variability in the $\mathrm{EF}$ of $\mathrm{Pb}$ and $\mathrm{V}$ across aerosols collected near the Australian coastline (Perron et al. 2020b) (Figs. 7 and 8) using values exceeding 10 as indicators of significant enrichment in coal and oil combustion aerosols, respectively. Measurement-based estimates of $\mathrm{EF}_{\mathrm{Pb}}$ and $\mathrm{EF}_{\mathrm{v}}$ suggested that the eastern Australian coast was largely influenced by anthropogenic emissions $\left(\mathrm{EF}_{\mathrm{Pb}}\right.$ and $\left.\mathrm{EF}_{\mathrm{v}}>10\right)$.
Table 3 A posteriori model estimates of $\mathrm{T}_{\mathrm{Fe}}$ source apportionment for each region considered, including the Australian marine regions (CSMR, NMR, TEMR, NWMR, and SWMR), as well as regions of the SO (HIMI and SR3). Atmospheric sources considered include dust (Dust), biomass burning (BB), oil combustion (Oil), and coal combustion (Coal). Results are in percent

\begin{tabular}{lllll}
\hline Region & Dust & BB & Oil & Coal \\
\hline CSMR & $70 \pm 13 \%$ & $24 \pm 11 \%$ & $5.2 \pm 2.7 \%$ & $1.5 \pm 1.0 \%$ \\
NMR & $67 \pm 9 \%$ & $30 \pm 9 \%$ & $2.0 \pm 1.5 \%$ & $0.23 \pm 0.13 \%$ \\
TEMR & $57 \pm 29 \%$ & $17 \pm 18 \%$ & $2.9 \pm 4.3 \%$ & $23 \pm 27 \%$ \\
NWMR & $92 \pm 13 \%$ & $7.3 \pm 3.0 \%$ & $0.38 \pm 0.19 \%$ & $0.13 \pm 0.07 \%$ \\
SWMR & $90 \pm 13 \%$ & $3.8 \pm 5.1 \%$ & $0.78 \pm 0.43 \%$ & $5.3 \pm 7.4 \%$ \\
HIMI & $93 \pm 14 \%$ & $5 \pm 14 \%$ & $1.0 \pm 0.6 \%$ & $0.9 \pm 2.6 \%$ \\
SR3 & $99 \pm 1 \%$ & $0.29 \pm 0.22 \%$ & $0.90 \pm 0.72 \%$ & $0.29 \pm 0.69 \%$ \\
\hline
\end{tabular}

Oil combustion sources contributed 17\%, $20 \%$ and $23 \%$ of $\mathrm{L}_{\mathrm{Fe}}$ over the industrial coats of the CSMR, TEMR, and SWMR, respectively. Over the SO, aerosol $\mathrm{L}_{\mathrm{Fe}}$ sources were predicted to originate from diverse sources including dust, oil combustion, and $\mathrm{BB}$ with relative contributions of $47 / 31 / 21 \%$ in the HIMI region and 59/28/12\% along the SR3 line. Anthropogenic signatures $\left(\mathrm{EF}_{\mathrm{v}}>10\right)$ were identified in $39 \%$ of aerosol samples collected in the two oceanic regions (23 data points). This result is consistent with previous field studies that have found the HNLC regions in the SO are associated with low mineral dust inputs (Boyd et al. 2007; Jickells and Moore 2015).

A posteriori model estimates of $\mathrm{T}_{\mathrm{Fe}}$ and $\mathrm{L}_{\mathrm{Fe}}$ provided much better agreement with observations following the inverse modeling technique. However, the a posteriori model did not capture the wide range of Fe solubilities obtained from field observations over the SO. Large uncertainties remained regarding the atmospheric $\mathrm{Fe}$ cycle, which included the role of aerosol size distribution, the relative contribution of dust, and combustion sources of $\mathrm{L}_{\mathrm{Fe}}$ to the atmospheric $\mathrm{L}_{\mathrm{Fe}}$ burden. An

Table 4 A posteriori model estimates of $L_{F e}$ for each region including the Australian marine regions (CSMR, NMR, TEMR, NWMR, and SWMR), as well as regions of the SO (HIMI and SR3). Atmospheric sources considered include dust (dust), biomass burning (BB), oil combustion (oil), and coal combustion (coal)

\begin{tabular}{lllll}
\hline Region & Dust & BB & Oil & Coal \\
\hline CSMR & $17 \pm 4 \%$ & $65 \pm 5 \%$ & $17 \pm 4 \%$ & $1.1 \pm 0.3 \%$ \\
NMR & $12 \pm 1 \%$ & $82 \pm 4 \%$ & $5.1 \pm 2.7 \%$ & $0.58 \pm 0.23 \%$ \\
TEMR & $23 \pm 16 \%$ & $52 \pm 18 \%$ & $20 \pm 21 \%$ & $4.7 \pm 4.1 \%$ \\
NWMR & $26 \pm 5 \%$ & $68 \pm 6 \%$ & $5.5 \pm 1.5 \%$ & $0.76 \pm 0.24 \%$ \\
SWMR & $58 \pm 9 \%$ & $15 \pm 17 \%$ & $23 \pm 13 \%$ & $3.7 \pm 1.5 \%$ \\
HIMI & $47 \pm 13 \%$ & $21 \pm 19 \%$ & $31 \pm 14 \%$ & $1.8 \pm 0.6 \%$ \\
SR3 & $59 \pm 13 \%$ & $12 \pm 6 \%$ & $28 \pm 14 \%$ & $1.7 \pm 0.9 \%$ \\
\hline
\end{tabular}




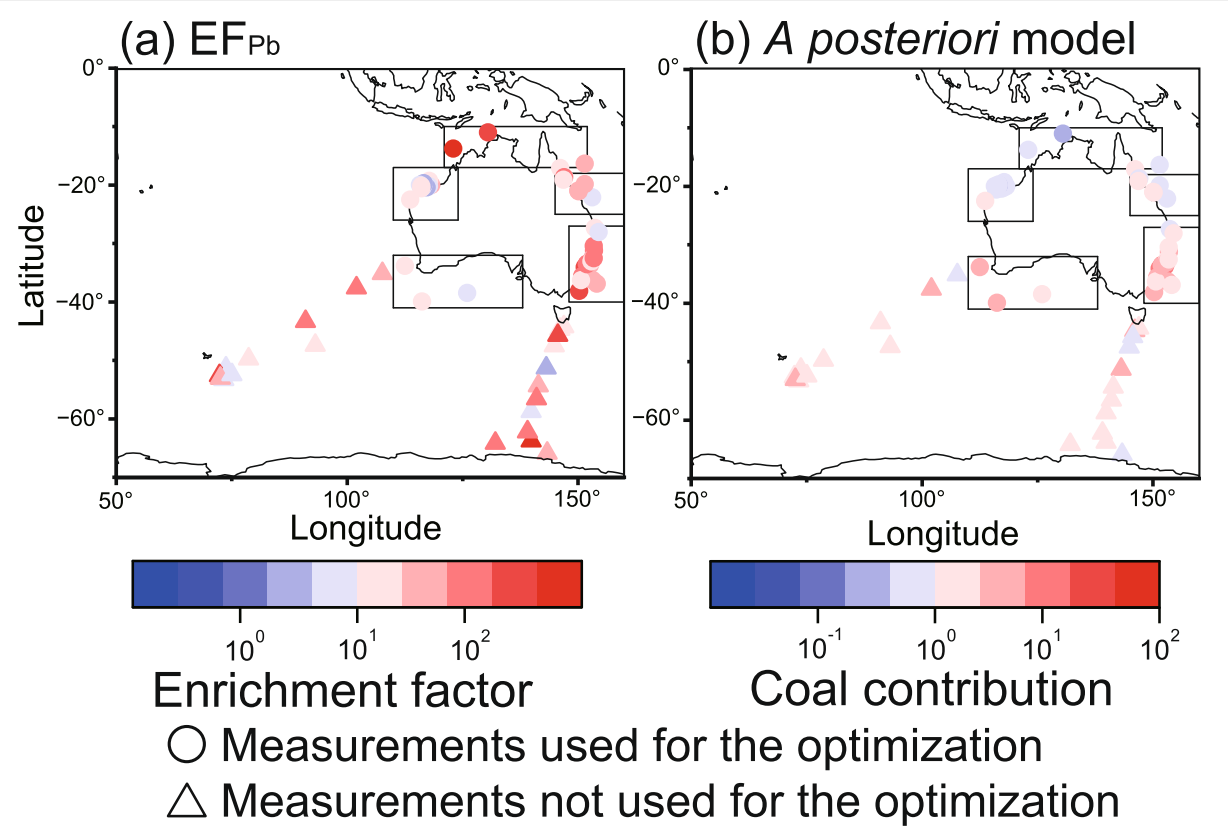

Fig. 7 Variability in a enrichment factor in lead $\left(E_{\mathrm{Pb}}\right)$ and $\mathbf{b}$ a posteriori model contribution of coal combustion sources to $L_{\mathrm{Fe}}(\%)$ in each sampled aerosol (or associated geographical grid cell)

additional possibility is that some Fe processing mechanisms may be missing from the model. For example, recent analysis of aerosol measurements with the IMPA CT model in a coastal city of China revealed Fe solubility enhanced in fog compared to other weather conditions such as haze and dust (Shi et al. 2020). The lower water content in the haze and dust particles could lead to the lower Fe dissolution rate in acidic solution and consequently suppress the Fe solubility (Ito and Shi 2016). On the other hand, the high Fe solubility in fog cannot be reproduced by the model, largely due to the ignorance of the fog enhancement. Continuous monitoring

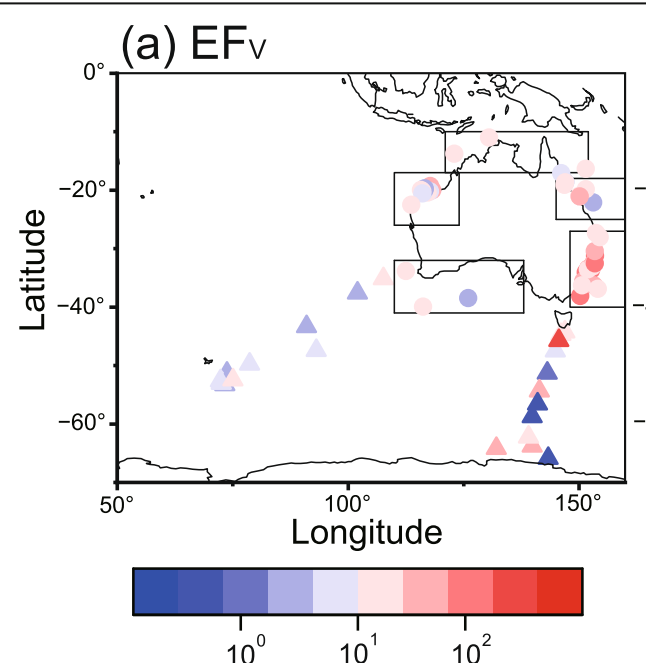

Enrichment factor (b) A posteriori model
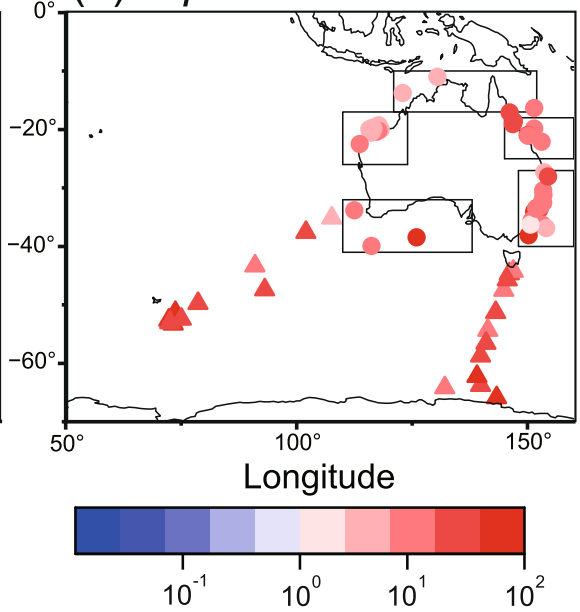

Oil contribution

$\bigcirc$ Measurements used for the optimization $\triangle$ Measurements not used for the optimization

Fig. 8 Variability in a enrichment factor in vanadium $\left(E F_{V}\right)$ and $\mathbf{b}$ a posteriori model contribution of oil combustion sources to $L_{\mathrm{Fe}}(\%)$ in each sampled aerosol (or associated geographical grid cell) 
observations of atmospheric $\mathrm{T}_{\mathrm{Fe}}$ and $\mathrm{L}_{\mathrm{Fe}}$ are necessary near source regions to better constrain the highly episodic nature of dust and bushfire emissions in the $\mathrm{SH}$. At the same time, laboratory experiments for Fe dissolution under fog conditions are needed to simulate the fog enhancement. Additional ship-board observations of multiple trace metals in aerosols (e.g., $\mathrm{V}, \mathrm{Pb}$, and $\mathrm{Fe}$ ) are necessary to better constrain aerosol $\mathrm{T}_{\mathrm{Fe}}$ and $\mathrm{L}_{\mathrm{Fe}}$ sources and transport, especially over remote regions such as the SO. Studies of stable Fe isotopes may offer additional constraints on the contribution from combustion or mineral dust sources to aerosol $\mathrm{T}_{\mathrm{Fe}}$ and $\mathrm{L}_{\mathrm{Fe}}$, if sources have distinct isotopic signatures (Mead et al. 2013; Kurisu et al. 2016; Conway et al. 2019). Finally, models must be continuously evaluated and adapted according to advances in field observations and laboratory measurements.

Overall, the a posteriori model outputs supported the qualitative findings based on the EFs, which highlighted distinct, region-dependent, dominant aerosol Fe sources across Australia (Winton et al. 2016; Perron et al. 2020b; Strzelec et al. 2020). However, the 0 model significantly underestimated $\mathrm{L}_{\mathrm{Fe}}$ at 28 data points out of 69 (Fig. 9a). Missing $\mathrm{L}_{\mathrm{Fe}}$ sources can be responsible for such $\mathrm{L}_{\mathrm{Fe}}$ underestimate. Thus, the unidentified source contribution was calculated from the negative bias in the model estimates less than one standard deviation of the averages from the measurements (Fig. 9). In the developed countries, most $\mathrm{Fe}$-containing aerosols are assumed to be collected prior to injection to the atmosphere by emission control device (e.g., scrubbers, cyclones, and electrostatic precipitator). Thus, the coal combustion sources generally presented a low contribution to $\mathrm{L}_{\mathrm{Fe}}$ around Australia, even in highly industrial regions such as the TEMR and the CSMR (Fig. 7). It has been suggested that the high $\mathrm{EF}_{\mathrm{Pb}}$ in the NMR (Fig. 7) might be associated with mining activities in northern Queensland (Perron et al. 2020b). Additional field observations near the various source regions are necessary to better constrain Fe emission from the sources and the size distribution of Fe-containing aerosols. Volcanic emissions near HIMI at the time of field sampling were not included in the model and might accentuate the under-representation of $\mathrm{L}_{\mathrm{Fe}}$ sources (Perron et al. pers.com.).

The spatial distribution of bushfire deposition flux and the contribution of sub-micron particles over the SO for 2017 were compared to mineral dust during the austral spring (September-October-November) when bushfires peaked in Australia (Fig. 10). The BB plume revealed that Australian bushfires could be a major source of $\mathrm{L}_{\mathrm{Fe}}$ to the eastern Indian Ocean, rather than the mineral dust during the austral spring. Sub-micron aerosols were the dominant contributor for BB in contrast to mineral dust. This is reasonably consistent with

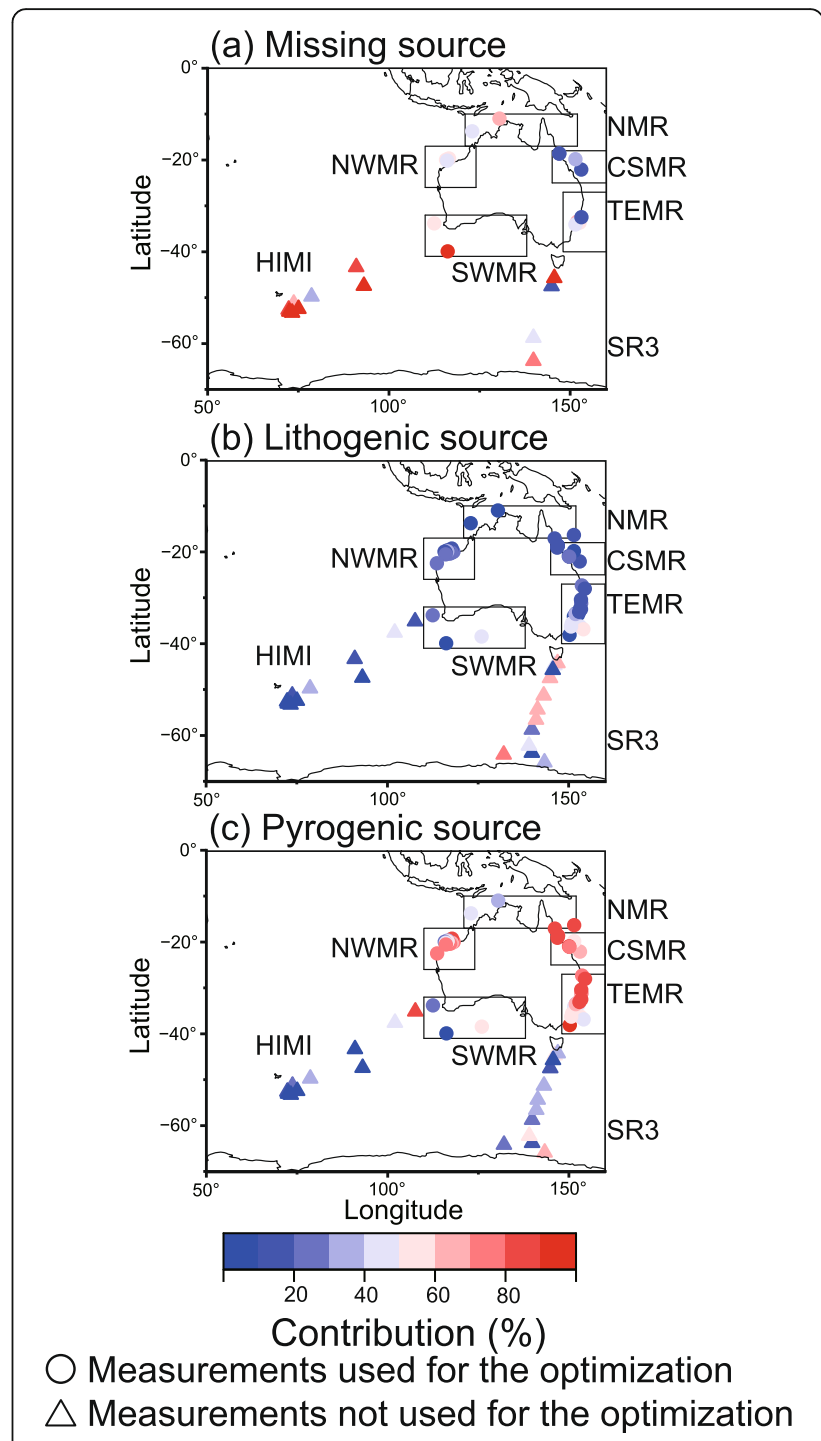

Fig. 9 Variability in the a posteriori model contribution of a missing source, b lithogenic source, and c pyrogenic source to $L_{F e}$ concentration in aerosols (\%)

field observations, which showed that higher Fe solubilities for finer aerosols influenced by $\mathrm{BB}$ and fossil fuel combustion sources but no such trend for mineral dustdominated aerosols (Siefert et al. 1999; Buck et al. 2010; Kumar et al. 2010; Trapp et al. 2010). Recent ocean biogeochemistry models included combustion sources (e.g., fuel combustion and biomass burning) of bioavailable $\mathrm{Fe}$ in addition to mineral dust (Hamilton et al. 2020; Hajima et al. 2020; Ito et al. 2020; Myriokefalitakis et al. 2020). However, the magnitude of their response to the atmospheric input of $\mathrm{L}_{\mathrm{Fe}}$ was substantially different. Further work will be needed to constrain the key parameters responsible for the response of ocean biogeochemistry to atmospheric deposition flux. 


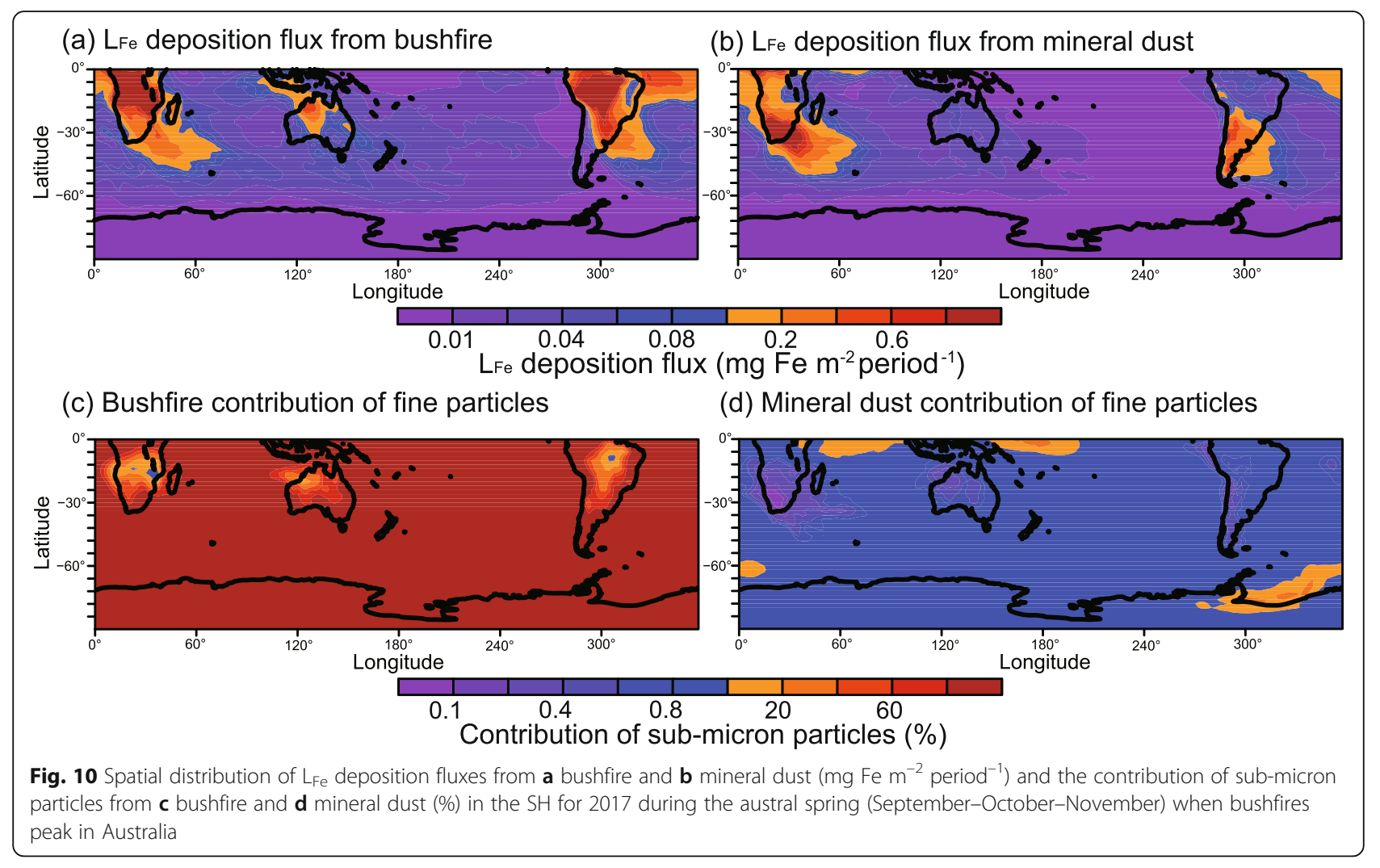

\section{Conclusions and implications}

The state-of-the-art GESAMP models showed the underestimates in high Fe solubilities reported in observational data over the $\mathrm{SO}$, resulting in $\mathrm{L}_{\mathrm{Fe}}$ concentrations 15 times smaller than field observations (Myriokefalitakis et al. 2018; Ito et al. 2019). If deposition fluxes calculated by these models were to be used to estimate dissolved $\mathrm{Fe}$ in marine biogeochemistry models, this could contribute to the underestimation of marine primary production in the SO. Such underestimates might be compensated partly by the upscaling of mineral dust emissions in the model to match the available measurements of atmospheric deposition fluxes (Albani et al. 2014; Ito et al. 2020). Such upscaling, however, could result in high biases in the predicted atmospheric concentrations over the $\mathrm{SH}$ (Huneeus et al. 2011; Albani et al. 2014). Moreover, such procedure might conceal other sources that are relatively minor in the present day but potentially important in the past and future.

In this study, the inverse model technique was applied to the IMPACT model to obtain the best agreement in $\mathrm{T}_{\mathrm{Fe}}$ concentrations between the model output and recent field measurements in aerosols collected over Australian coastal regions $\left(110^{\circ} \mathrm{E}-160^{\circ} \mathrm{E}\right.$ and $\left.10^{\circ} \mathrm{S}-41^{\circ} \mathrm{S}\right)$. The a posteriori model suggested that a large fraction (between $57 \%$ and $99 \%$ ) of $\mathrm{T}_{\mathrm{Fe}}$ was delivered by dust sources, while the mineral dust aerosols only contributed between $12 \%$ and $58 \%$ of the atmospheric $\mathrm{L}_{\mathrm{Fe}}$. Instead of mineral dust, bushfires were major sources (between $15 \%$ and $82 \%$ ) of $L_{F}$ over Australian coastal waters. Such BB source may become important for the ocean biogeochemistry in the SO if policy and climate follow the intermediate Representative Concentration Pathway 4.5 trajectory (Hamilton et al. 2020). This is already evident through the devastating bushfires which occurred in the 2019-2020 austral summer. However, the source apportionment of $\mathrm{L}_{\mathrm{Fe}}$ in atmospheric chemistry models is extremely sensitive to Fe content and solubility in $\mathrm{BB}$ aerosols over the SH (Ito 2012; Hamilton et al. 2019). The IMPACT model assumed Fe dissolution rate constants for $\mathrm{BB}$ aerosols to be the same as those reported for coal fly ash, although Fe dissolution rates depended on the $\mathrm{pH}$, ambient temperature, the degree of solution saturation, and on the competition for oxalate between $\mathrm{Fe}$ on the surface of particles and dissolved Fe from the aerosols in the model (Fu et al. 2012; Chen and Grassian 2013; Ito 2015). On the other hand, the IMPACT model considered different kinetic dissolution behaviors of mineral dust according to different types of Fe (Ito and Shi 2016). Additional laboratory experiments in conjunction with field observations are required to better constrain $\mathrm{L}_{\mathrm{Fe}}$ in combustion aerosols. 


\section{Supplementary information}

Supplementary information accompanies this paper at https://doi.org/10. 1186/s40645-020-00357-9.

Additional file 1: Table S1. Latitude (Lat), longitude (Lon), date, month, year, total Fe concentration $\left(\mathrm{T}_{\mathrm{Fe}}, \mathrm{ng} \mathrm{m}^{-3}\right)$, and labile Fe concentration $\left(\mathrm{L}_{\mathrm{Fe}}\right.$, $\mathrm{ng} \mathrm{m}^{-3}$ ) for observation (Obs) and a posteriori model estimate (Model). Table S2. Latitude (Lat), longitude (Lon), enrichment factor in lead ( $E F_{\mathrm{Pb}}$ ), modeled contribution of coal combustion sources (Coal) to $\mathrm{L}_{\mathrm{Fe}}$ concentration (\%), enrichment factor in vanadium (EFv), and modeled contribution of oil combustion sources (Oil) to $L_{\mathrm{Fe}}$ concentration (\%), and modeled contribution of lithogenic (Lith) and pyrogenic (Pyro) sources to $\mathrm{L}_{\mathrm{Fe}}$ concentration in aerosols (\%). The missing source contribution was estimated from the negative bias in the model estimates less than one standard deviation of the averages from the measurements.

\section{Abbreviations}

AA: Ammonium acetate; AERONET: AErosol RObotic NETwork; AOD: Aerosol optical depth; BB: Biomass burning; BC: Black carbon; CSMR: Coral Sea Marine Region; DMS: Dimethylsulfide; EF: Enrichment factor; GESAMP: Group of Experts on the Scientific Aspects of Marine Environmental Protection; GMAO: Global Modeling and Assimilation Office; HIMI: Heard Islands and McDonald Islands; HNLC: High-nutrient low-chlorophyll; IMPACT: Integrated Massively Parallel Atmospheric Chemical Transport; LFe: Labile Fe; MERRA2: Modern Era Retrospective analysis for Research and Applications 2; MODIS: MODerate resolution Imaging Spectroradiometer; NASA: National Aeronautics and Space Administration; NH: Northern Hemisphere; NMR: North Marine Region; NWMR: North West Marine Region; OC: Organic carbon; POM: Particulate organic matter; SH: Southern Hemisphere; SMAP: Soil moisture active passive; SO: Southern Ocean; SWMR: South West Marine Region; TEMR: Temperate East Marine Region; $T_{\mathrm{Fe}}$ : Total Fe; UHPW: Ultra-high purity water

\section{Acknowledgements}

Numerical simulations were performed using the Hewlett-Packard Enterprise (HPE) Apollo at the Japan Agency for Marine-Earth Science and Technology (JAMSTEC). The Modern Era Retrospective analysis for Research and Applications 2 (MERRA-2) data have been provided by the Global Modeling and Assimilation Office (GMAO) at NASA Goddard Space Flight Center.

\section{Authors' contributions}

Al and MMGP initiated the modeling collaboration with recent observational data set. Al conceived the optimization and carried out the modeling study. $M M G, B C P, M S, M G-R, P W B$, and ARB contributed measured data. All authors read and approved the final manuscript.

\section{Funding}

The support for this research was provided to AI by JSPS KAKENHI Grant Number $20 \mathrm{H} 04329$ and $18 \mathrm{H} 04143$, and Integrated Research Program for Advancing Climate Models (TOUGOU) Grant Number JPMXD0717935715 from the Ministry of Education, Culture, Sports, Science and Technology (MEXT), Japan. This work was supported by grants from the Australian Research Council, Future Fellowship (FT130100037 to ARB), through the Antarctic Climate and Ecosystems Cooperative Research Centre (ACE CRC) and from fieldwork support through the Australian Marine National Facility (MNF)

\section{Availability of data and materials}

The datasets supporting the conclusions of this article are included within the article and its additional files.

\section{Competing interests}

The authors declare that they have no competing interests.

\section{Author details}

${ }^{1}$ Yokohama Institute for Earth Sciences, JAMSTEC, Yokohama, Kanagawa 236-0001, Japan. ${ }^{2}$ Institute for Marine and Antarctic Studies, University of Tasmania, Battery Point, Tasmania, Australia. ${ }^{3}$ Antarctic Climate and Ecosystems CRC, University of Tasmania, Battery Point, Tasmania, Australia.
Received: 20 January 2020 Accepted: 28 July 2020

Published online: 26 August 2020

\section{References}

Adebiyi AA, Kok JF, Wang Y, Ito A, Ridley DA, Nabat P, Zhao C (2020), Dust Constraints from joint Observational-Modelling-experiMental analysis (DustCOMM): Comparison with measurements and model simulations. Atmos Chem Phys 20: 541-570. doi.org/https://doi.org/10.5194/acp-20-829-2020.

Albani S, Mahowald NM, Perry AT, Scanza RA, Zender CS, Heavens NG, Maggi V, Kok JF, Otto-Bliesner BL (2014) Improved dust representation in the Community Atmosphere Model. J Adv Model Earth Syst 6:541-570. https://doi.org/10.1002/2013MS000279

Baddock M, Parsons K, Strong C, Leys J, Mctainsh G (2015) Drivers of Australian dust: A case study of frontal winds and dust dynamics in the lower lake Eyre basin. Earth Surf Process Landforms 40:1982-1988. https://doi.org/10.1002/ esp.3773

Baker AR, Croot PL (2010) Atmospheric and marine controls on aerosol iron solubility in seawater. Mar Chem 120:4-13. https://doi.org/10.1016/j. marchem.2008.09.003

Baker AR, Landing WM, Bucciarelli E, Cheize M, Fietz S, Hayes CT, Kadko D, Morton PL, Rogan N, Sarthou G, Shelley RU, Shi Z, Shiller AM, van Hulten MMP (2016) Trace element and isotope deposition across the air-sea interface: progress and research needs. Philos Trans A. https://doi.org/10. 1098/rsta.2016.0190

Bowler JM (1976) Aridity in Australia: Age, origins and expression in aeolian landforms and sediments. Earth Sci Rev 12:279-310. https://doi.org/10.1016/ 0012-8252(76)90008-8

Boyd PW, Ellwood MJ (2010) The biogeochemical cycle of iron in the ocean. Nat Geosci 3:675-682

Boyd PW, Jickells TD, Law CS, Blain S, Boyle EA, Buesseler KO, Coale KH, Cullen JJ, De Baar HJW, Follows M, Harvey M, Lancelot C, Levasseur M, Owens NPJ, Pollard R, Rivkin RB, Sarmiento J, Schoemann V, Smetacek V, Takeda S, Tsuda A, Turner S, Watson AJ (2007) Mesoscale iron enrichment experiments 19932005: synthesis and future directions. Science 315:612-617. https://doi.org/10. 1126/science.1131669

Boyd PW, Watson AJ, Law CS, Abraham ER, Trull TW, Murdoch R, Bakker DCE, Bowie AR, Buesseler KO, Chang H, Charette M, Croot PL, Downing K, Frew R, Gall M, Hadfield M, Hall J, Harvey M, Jameson G, LaRoche J, Liddicoat M, Ling R, Maldonado MT, Mckay RMM, Nodder S, Pickmere S, Pridmore R, Rintoul S, Safi K, Sutton P, Strzepek RF, Tanneberger K, Turner S, Waite A, Zeldis J (2000) A mesoscale phytoplankton bloom in the polar Southern Ocean stimulated by iron fertilization. Nature 407:695-702. https://doi.org/10.1038/35037500

Buck CS, Landing WM, Resing JA (2010) Particle size and aerosol iron solubility: a high resolution analysis of Atlantic aerosols. Mar Chem 120:14-24. https://doi. org/10.1016/j.marchem.2008.11.002

Chen H, Grassian VH (2013) Iron dissolution of dust source materials during simulated acidic processing: the effect of sulfuric, acetic, and oxalic acids. Environ Sci Technol 47:10312-10321. https://doi.org/10.1021/es401285s

Conway TM, Hamilton DS, Shelley RU, Aguilar-Islas AM, Landing WM, Mahowald NM, John SG (2019) Tracing and constraining anthropogenic aerosol iron fluxes to the North Atlantic Ocean using iron isotopes. Nat Commun 10:110. https://doi.org/10.1038/s41467-019-10457-w

Cutter G, Casciotti K, Croot PL, Geibert W, Heimburger L-E, Lohan MC, Planquette $H$, van de Flierdt T (2017) Sampling and Sample-handling Protocols for GEOTRACES Cruises v.3.

de Baar HJW, de Jong JTM, Bakker DCE, Löscher BM, Veth C, Bathmann U, Smetacek V (1995) Importance of iron for plankton blooms and carbon dioxide drawdown in the Southern Ocean. Nature 373:412-415. https://doi.org/10.1038/373412a0

Enting IG, Trudinger CM, Francey RJ (1995) A synthesis inversion of the concentration and $\delta^{13} \mathrm{C}$ of atmospheric $\mathrm{CO}_{2}$. Tellus Ser B 47B:35-52 https://doi.org/10.3402/tellusb.v47i1-2.15998

Ferek RJ, Reid JS, Hobbs PV, Blake DR, Liousse C (1998) Emission factors of hydrocarbons, halocarbons, trace gases and particles from biomass burning in Brazil. J Geophys Res 103(D24):32107-32118. https://doi.org/10.1029/ 98JD00692

Fu H, Lin J, Shang G, Dong W, Grassian VH, Carmichael GR, Li Y, Chen J (2012) Solubility of iron from combustion source particles in acidic media linked to iron speciation. Environ Sci Technol 46:11119-11127. https://doi.org/10.1021/ es302558m 
Fung IY, Meyn SK, Tegen I, Doney SC, John JG, Bishop JKB (2000) Iron supply and demand in the upper ocean. Global Biogeochem Cy 14:281-295

Gantt B, Johnson MS, Meskhidze N, Sciare J, Ovadnevaite J, Ceburnis D, O'Dowd CD (2012) Model evaluation of marine primary organic aerosol emission schemes. Atmos Chem Phys 12:8553-8566. https://doi.org/10.5194/acp-12-8553-2012

Gao Y, Xu G, Zhan J, Zhang J, Li W, Lin Q, Chen L, Lin H (2013) Spatial and particle size distributions of atmospheric dissolvable iron in aerosols and its input to the Southern Ocean and coastal East Antarctica. J Geophys Res Atmos 118:12634-12648. https://doi.org/10.1002/2013JD020367

Gelaro R, McCarty W, Suárez MJ, Todling R, Molod A, Takacs L, Randles CA, Darmenov A, Bosilovich MG, Reichle R, Wargan K, Coy L, Cullather R, Draper C, Akella S, Buchard V, Conaty A, da Silvaa AM, Gu W, Kim G-K, Koster R, Lucchesi R, Merkova D, Nielsen JE, Partyka G, Pawson S, Putman W, Rienecker M, Schubert SD, Sienkiewicz M, Zhao B (2017) The modern-era retrospective analysis for research and applications, version 2 (MERRA-2). J Clim 30:54195454. https://doi.org/10.1029/2009GL040000

Ginoux P, Chin M, Tegen I, Prospero JM, Holben B, Dubovik O, Lin S-J (2001) Sources and distributions of dust aerosols simulated with the GOCART model. J Geophys Res 106: 20255-20274. https://doi.org/10.1029/ 2000JD000053.

Grand MM, Measures Cl, Hatta M, Hiscock WT, Buck CS, Landing WM (2015) Dust deposition in the eastern Indian Ocean: The ocean perspective from Antarctica to the Bay of Bengal. Global Biogeochem Cy 29:357-374 https://doi.org/10.1002/2014GB004920

Hackenberg SC, Andrews SJ, Airs R, Arnold SR, Bouman HA, Brewin RJW, Chance RJ, Cummings D, Dall'Olmo G, Lewis AC, Minaeian JK, Reifel KM, Small A, Tarran GA, Tilstone GH, Carpenter $\amalg$ (2017) Potential controls of isoprene in the surface ocean. Global Biogeochem Cy 31:644-662. https://doi.org/10. 1002/2016GB005531

Hajima T, Watanabe M, Yamamoto A, Tatebe H, Noguchi M, Abe M, Ohgaito R, Ito A, Yamazaki D, Okajima H, Ito A, Takata K, Ogochi K, Watanabe S, Kawamiya M (2020) Description of the MIROC-ES2L Earth system model and evaluation of its climate-biogeochemical processes and feedbacks. Geosci Model Dev 12:2727-2765. https://doi.org/10.5194/gmd-2019-275

Hamilton DS, Moore JK, Arneth A, Bond TC, Carslaw KS, Hanston S, Ito A, Kaplan JO, Lindsay K, Nieradzik L, Rathod SD, Scanza RA, Mahowald NM (2020) Impact of changes to the atmospheric soluble iron deposition flux on ocean biogeochemical cycles in the Anthropocene. Global Biogeochem Cy 34: e2019GB006448. https://doi.org/10.1029/2019GB006448

Hamilton DS, Scanza RA, Feng Y, Guinness J, Kok JF, Li L, Liu X, Rathod SD, Wan JS, Wu M, Mahowald NM (2019) Improved methodologies for Earth system modelling of atmospheric soluble iron and observation comparisons using the Mechanism of Intermediate complexity for Modelling Iron (MIMI v.1.0). Geosci Model Dev 12: 3835-3862. https://doi.org/10.5194/gmd-12-3835-2019.

Heimburger A, Losno R, Triquet S (2013) Solubility of iron and other trace elements in rainwater collected on the Kerguelen Islands (South Indian Ocean). Biogeosciences 10:6617-6628. https://doi.org/10.5194/bg-10-6617-2013

Hoelzemann JJ, Schultz MG, Brasseur GP, Granier C, Simon M (2004) Global Wildland Fire Emission Model (GWEM): evaluating the use of global area burnt satellite data. J Geophys Res 109:D14S04. https://doi.org/10.1029/ 2003JD003666

Hoesly RM, Smith SJ, Feng L, Klimont Z, Janssens-Maenhout G, Pitkanen T, Seibert JJ, Vu L, Andres RJ, Bolt RM, Bond TC, Dawidowski L, Kholod N, Kurokawa J, Li M, Liu L, Lu Z, Moura MCP, ÓRourke PR, Zhang Q (2018) Historical (17502014) anthropogenic emissions of reactive gases and aerosols from the Community Emissions Data System (CEDS). Geosci Model Dev 11:369-408. https://doi.org/10.5194/gmd-11-369-2018

Hsu SC, Wong GTF, Gong GC, Shiah FK, Huang YT, Kao SJ, Tsai F, Candice Lung SC, Lin FJ, Lin II, Hung CC, Tseng CM (2010) Sources, solubility, and dry deposition of aerosol trace elements over the East China Sea. Mar Chem 120: 116-127. https://doi.org/10.1016/j.marchem.2008.10.003

Huneeus N, Schulz M, Balkanski Y, Griesfeller J, Prospero J, Kinne S, Bauer S, Boucher O, Chin M, Dentener F, Diehl T, Easter R, Fillmore D, Ghan S, Ginoux P, Grini A, Horowitz L, Koch D, Krol MC, Landing W, Liu X, Mahowald N, Miller R, Morcrette J-J, Myhre G, Penner J, Perlwitz J, Stier P, Takemura T, Zender CS (2011) Global dust model intercomparison in AeroCom phase I. Atmos Chem Phys 11:7781-7816. https://doi.org/10.5194/acp-11-7781-2011

Ishizuka M, Mikami M, Leys J, Yamada Y, Heidenreich S, Shao Y, McTainsh GH (2008) Effects of soil moisture and dried raindroplet crust on saltation and dust emission. J Geophys Res 113:D24212. https://doi.org/10.1029/ 2008JD009955
Ito A (2011) Mega fire emissions in Siberia: potential supply of bioavailable iron from forests to the ocean. Biogeosciences 8: 1679-1697. https://doi.org/10. 5194/bg-8-1679-2011.

Ito A (2012) Contrasting the effect of iron mobilization on soluble iron deposition to the ocean in the Northern and Southern Hemispheres. J Meteorol Soc Japan 90A:167-188. https://doi.org/10.2151/jmsj.2012-A09

Ito A (2013) Global modeling study of potentially bioavailable iron input from shipboard aerosol sources to the ocean. Global Biogeochem Cy 27:1-10. https://doi.org/10.1029/2012GB004378

Ito A (2015) Atmospheric processing of combustion aerosols as a source of bioavailable iron. Environ Sci Technol Lett 2:70-75. https://doi.org/10.1021/ acs.estlett.5b00007

Ito A, Feng Y (2010) Role of dust alkalinity in acid mobilization of iron. Atmos Chem Phys 10:9237-9250. https://doi.org/10.5194/acp-10-9237-2010

Ito A, Kok JF (2017) Do dust emissions from sparsely vegetated regions dominate atmospheric iron supply to the Southern Ocean? I Geophys Res Atmos 122: 3987-4002. https://doi.org/10.1002/2016JD025939

Ito A, Lin G, Penner JE (2015) Global modeling study of soluble organic nitrogen from open biomass burning. Atmos Environ 121:103-112. https://doi.org/10. 1016/j.atmosenv.2015.01.031

Ito A, Lin G, Penner JE (2018) Radiative forcing by light-absorbing aerosols of pyrogenetic iron oxides. Sci Rep 8:7347. https://doi.org/10.1038/s41598-018-25756-3

Ito A, Myriokefalitakis S, Kanakidou M, Mahowald NM, Scanza RA, Hamilton DS, Baker AR, Jickells T, Sarin M, Bikkina S, Gao Y, Shelley RU, Buck CS, Landing WM, Bowie AR, Perron MMG, Guieu C, Meskhidze N, Johnson MS, Feng Y, Kok JF, Nenes A, Duce RA (2019) Pyrogenic iron: the missing link to high iron solubility in aerosols. Sci Adv 5: eaau7671. https://doi.org/10.1126/sciadv. aau7671

Ito A, Penner JE (2004) Global estimates of biomass burning emissions based on satellite imagery for the year 2000. J Geophys Res 109:D14S05. https://doi. org/10.1029/2003JD004423

Ito A, Penner JE (2005) Historical emissions of carbonaceous aerosols from biomass and fossil fuel burning for the period 1870-2000. Global Biogeochem Cy 19:GB2028. https://doi.org/10.1029/2004GB002374

Ito A, Shi Z (2016) Delivery of anthropogenic bioavailable iron from mineral dust and combustion aerosols to the ocean. Atmos Chem Phys 16:85-99. https:// doi.org/10.5194/acp-16-85-2016

Ito A, Sillman S, Penner JE (2007) Effects of additional nonmethane volatile organic compounds, organic nitrates, and direct emissions of oxygenated organic species on global tropospheric chemistry. J Geophys Res Atmos 112: D06309. https://doi.org/10.1029/2005JD006556

Ito A, Ye Y, Yamamoto A, Watanabe M, Aita MN (2020). Responses of ocean biogeochemistry to atmospheric supply of lithogenic and pyrogenic ironcontaining aerosols. Geol Mag 157: 741-756. https://doi.org/10.1017/ S0016756819001080.

Jickells TD, An ZS, Andersen KK, Baker AR, Bergametti G, Brooks N, Cao JJ, Boyd PW, Duce RA, Hunter KA, Kawahata H, Kubilay N, LaRoche J, Liss PS, Mahowald N, Prospero JM, Ridgwell AJ, Tegen I, Torres R (2005) Global iron connections between desert dust, ocean biogeochemistry, and climate. Science 308:67-71. https://doi.org/10.1126/science.1105959

Jickells TD, Moore MC (2015) The importance of atmospheric deposition for ocean productivity. Annu Rev Ecol Evol Syst 46:481-501. https://doi.org/10. 1146/annurev-ecolsys-112414-054118

Johnson MS, Meskhidze N (2013) Atmospheric dissolved iron deposition to the global oceans: effects of oxalate-promoted Fe dissolution, photochemical redox cycling, and dust mineralogy. Geosci Model Dev 6:1137-1155. https://doi.org/10.5194/gmd-6-1137-2013

Journet E, Balkanski Y, Harrison SP (2014) A new data set of soil mineralogy for dust-cycle modelling. Atmos Chem Phys 14:3801-3816. https://doi.org/10. 5194/acp-14-3801-2014

Keller CA, Long MS, Yantosca RM, Da Silva AM, Pawson S, Jacob DJ (2014) HEMCO v1.0: a versatile, ESMF-compliant component for calculating emissions in atmospheric models. Geosci Model Dev 7:1409-1417. https://doi.org/10.5194/gmd-7-1409-2014

Kok JF, Ridley DA, Zhou Q, Miller RL, Zhao C, Heald CL, Ward DS, Albani S, Haustein K (2014) An improved dust emission model_-Part 1: model description and comparison against measurements. Atmos Chem Phys 14: 13023-13041. https://doi.org/10.5194/acp-14-13023-2014

Kumar A, Sarin MM, Srinivas B (2010) Aerosol iron solubility over Bay of Bengal: Role of anthropogenic sources and chemical processing. Marine Chemistry 121:167-175. https://doi.org/10.1016/j.marchem.2010.04.005 
Kurisu M, Takahashi Y, lizuka T, Uematsu M. (2016) Very low isotope ratio of iron in fine aerosols related to its contribution to the surface ocean. J Geophys Res Atmos 121: 11119-11136. https://doi.org/10.1002/2016JD024957.

Li F, Ginoux P, Ramaswamy V (2008) Distribution, transport, and deposition of mineral dust in the Southern Ocean and Antarctica: Contribution of major sources. J Geophys Res 113. https://doi.org/10.1029/2007JD009190

Li W, Xu L, Liu X, Shi Z, Yao X, Gao H, Chen J, Chen B, Zhang D, Zhang X, Wang W (2017) Air pollution-aerosol interactions produce more bioavailable iron for ocean ecosystems. Sci Adv 3:e1601749. https://doi.org/10.1126/sciadv.1601749

Lin G, Sillman S, Penner JE, Ito A (2014) Global modeling of SOA: the use of different mechanisms for aqueous phase formation. Atmos Chem Phys 14: 5451-5475. https://doi.org/10.5194/acp-14-5451-2014

Lindsley WG (2016) Filter pore size and aerosol sample collection. In: NIOSH Manual of Analytical Methods. NIOSH, Cincinnati, Ohio, pp 1-14

Liu XH, Penner JE, Herzog M (2005) Global modeling of aerosol dynamics: Model description, evaluation, and interactions between sulfate and nonsulfate aerosols. J Geophys Res 110:D18206. https://doi.org/10.1029/2004JD005674

Longo AF, Feng Y, Lai B, Landing WM, Shelley RU, Nenes A, Mihalopoulos N, Violaki K, Ingall ED (2016) Influence of atmospheric processes on the solubility and composition of iron in Saharan dust. Environ Sci Technol 50: 6912-6920. https://doi.org/10.1021/acs.est.6b02605

Luo C, Mahowald N, Bond T, Chuang PY, Artaxo P, Siefert R, Chen Y, Schauer J (2008) Combustion iron distribution and deposition. Global Biogeochem Cy 22. https://doi.org/10.1029/2007GB002964

Mackie DS, Boyd PW, Hunter KA, McTainsh GH (2005) Simulating the cloud processing of iron in Australian dust: $\mathrm{pH}$ and dust concentration. Geophys Res Lett 32:L06809. https://doi.org/10.1029/2004GL022122

Mackie DS, Boyd PW, McTainsh GH, Tindale NW, Westberry TK, Hunter KA (2008) Biogeochemistry of iron in Australian dust: From eolian uplift to marine uptake. Geochemistry, Geophys Geosystems 9. https://doi.org/10.1029/ 2007GC001813

Mahowald NM, Baker AR, Bergametti G, Brooks N, Duce RA, Jickells TD, Kubilay N, Prospero JM, Tegen I (2005) Atmospheric global dust cycle and iron inputs to the ocean. Global Biogeochem Cy 19. https://doi.org/10.1029/ 2004GB002402

Mahowald NM, Engelstaedter S, Luo C, Sealy A, Artaxo P, Benitez-Nelson CR, Bonnet S, Chen Y, Chuang PY, Cohen DD, Dulac F, Herut B, Johansen AM, Kubilay N, Losno R, Maenhaut W, Paytan A, Prospero JM, Shank LM, Siefert RL (2009) Atmospheric iron deposition: Global distribution, variability, and human perturbations. Ann Rev Mar Sci 1:245-278. https://doi.org/10.1146/ annurev.marine.010908.163727

Mahowald NM, Hamilton DS, Mackey KRM, Moore JK, Baker AR, Scanza RA, Zhang Y (2018) Aerosol trace metal leaching and impacts on marine microorganisms. Nat Commun:9. https://doi.org/10.1038/s41467-018-04970-7

Mallet MD, Desservettaz MJ, Miljevic B, Milic A, Ristovski ZD, Alroe J, Cravigan LT, Rohan Jayaratne E, Paton-Walsh C, Griffith DWT, Wilson SR, Kettlewell G, Van Der Schoot MV, Selleck P, Reisen F, Lawson SJ, Ward J, Harnwell J, Cheng M, Gillett RW, Molloy SB, Howard D, Nelson PF, Morrison AL, Edwards GC, Williams AG, Chambers SD, Werczynski S, Williams LR, Winton VHL, Atkinson B, Wang X, Keywood MD (2017) Biomass burning emissions in north Australia during the early dry season: An overview of the 2014 SAFIRED campaign. Atmos Chem Phys:1713681-1713697. https://doi.org/10.5194/acp17-13681-2017

Martin JH, Fitzwater SE (1988) Iron deficiency limits phytoplankton growth in the north-east Pacific subarctic. Nature 336:403-405. https://doi.org/10.1038/ $332141 \mathrm{a} 0$

Matsui H, Mahowald NM, Moteki N, Hamilton DS, Ohata S, Yoshida A, Koike M, Scanza RA, Flanner MG (2018) Anthropogenic combustion iron as a complex climate forcer. Nat Commun 9. https://doi.org/10.1038/s41467-018-03997-0

McLennan SM (2001) Relationships between the trace element composition of sedimentary rocks and upper continental crust. Geochemistry, Geophys Geosystems 2. https://doi.org/10.1029/2000GC000109

Mead C, Herckes P, Majestic BJ, Anbar AD (2013) Source apportionment of aerosol iron in the marine environment using iron isotope analysis. Geophys Res Lett 40: 5722-5727. https://doi.org/10.1002/2013GL057713.

Meskhidze N, Völker C, Al-Abadleh HA, Barbeau K, Bressac M, Buck C, Bundy RM Croot P, Feng Y, Ito A, Johansen AM, Landing WM, Mao J, Myriokefalitakis S, Ohnemus D, Pasquier B and Ye Y (2019) Perspective on identifying and characterizing the processes controlling iron speciation and residence time at the atmosphere-ocean interface. Mar Chem 217: 103704. https://doi.org/ 10.1016/j.marchem.2019.103704.
Myriokefalitakis S, Daskalakis N, Mihalopoulos N, Baker AR, Nenes A, Kanakidou M (2015) Changes in dissolved iron deposition to the oceans driven by human activity: a 3-D global modelling study. Biogeosciences 12:3973-3992. https:// doi.org/10.5194/bg-12-3973-2015

Myriokefalitakis S, Gröger M, Hieronymus J, Döscher R (2020) An explicit estimate of the atmospheric nutrient impact on global oceanic productivity. Ocean Sci Discuss, in review. https://doi.org/10.5194/os-2020-27

Myriokefalitakis S, Ito A, Kanakidou M, Nenes A, Krol MC, Mahowald NM, Scanza RA, Hamilton DS, Johnson MS, Meskhidze N, Kok JF, Guieu C, Baker AR, Jickells TD, Sarin MM, Bikkina S, Shelley R, Bowie A, Perron MMG, Duce RA (2018) The GESAMP atmospheric iron deposition model intercomparison study. Biogeosciences 15:6659-6684. https://doi.org/10. 5194/bg-15-6659-2018

Neff PD, Bertler NAN (2015) Trajectory modeling of modern dust transport to the Southern Ocean and Antarctica. J Geophys Res Atmos 120:9303-9322. https://doi.org/10.1002/2015JD023304

Pan X, Ichoku C, Chin M, Bian H, Darmenov A, Colarco P, Ellison L, Kucsera T, da Silva A, Wang J, Oda T, Cui G (2020) Six global biomass burning emission datasets: intercomparison and application in one global aerosol model. Atmos Chem Phys 20:969-994. https://doi.org/10.5194/acp-20-969-2020

Paton-Walsh C, Smith TELL, Young EL, Griffith DWTT, Guérette É-A, Guérette A (2014) New emission factors for Australian vegetation fires measured using open-path Fourier transform infrared spectroscopy - Part 1: Methods and Australian temperate forest fires. Atmos Chem Phys 14:11313-11333. https:// doi.org/10.5194/acp-14-11313-2014

Perron MMG, Proemse BC, Strzelec M, Gault-Ringold M, Boyd PW, Sanz Rodriguez E, Paull B, Bowie AR (2020b) Origin transport and deposition of aerosol iron to Australian coastal waters. Atmos Environ 228:117432. https://doi.org/10. 1016/j.atmosenv.2020.117432

Perron MMG, Strzelec M, Gault-Ringold M, Proemse BC, Boyd PW, Bowie AR (2020a) Assessment of leaching protocols to determine the solubility of trace metals in aerosols. Talanta 208:120377. https://doi.org/10.1016/j.talanta.2019.120377

Prospero JM, Ginoux P, Torres O, Nicholson SE, Gill TE (2002) Environmental characterization of global sources of atmospheric soil dust identified with the Nimbus 7 Total Ozone Mapping Spectrometer (TOMS) absorbing aerosol product. Rev Geophys 40:1002. https://doi.org/10.1029/2000RG000095

Reddington CL, Spracklen DV, Artaxo P, Ridley DA, Rizzo LV, Arana A (2016) Analysis of particulate emissions from tropical biomass burning using a global aerosol model and long-term surface observations. Atmos Chem Phys 16:11083-11106. https://doi.org/10.5194/acp-16-11083-2016

Rotman DA, Atherton CS, Bergmann DJ, Cameron-Smith PJ, Chuang CC, Connell PS, Dignon JE, Franz A, Grant KE, Kinnison DE, Molenkamp CR, Proctor DD, Tannahill JR (2004) IMPACT, the LLNL 3-D global atmospheric chemical transport model for the combined troposphere and stratosphere: Model description and analysis of ozone and other trace gases. J Geophys Res D Atmos 109. https://doi.org/10.1029/2002jd003155

Sato H, Itoh A, Kohyama T (2007) SEIB-DGVM: A new dynamic global vegetation model using a spatially explicit individual-based approach. Ecol Model 200: 279-307. https://doi.org/10.1016/j.ecolmodel.2006.09.006

Schroth AW, Crusius J, Sholkovitz ER, Bostick BC (2009) Iron solubility driven by speciation in dust sources to the ocean. Nat Geosci 2:337-340. https://doi. org/10.1038/ngeo501

Sedwick PN, Sholkovitz ER, Church TM (2007) Impact of anthropogenic combustion emissions on the fractional solubility of aerosol iron: Evidence from the Sargasso Sea. Geochemistry, Geophys Geosystems 8. https://doi. org/10.1029/2007GC001586

Shi J, Guan Y, Ito A, Gao H, Yao X, Baker AR, Zhang D (2020) High productivity of soluble iron by aerosol acidification in fog. Geophys Res Lett 47: e2019GL086124. https://doi.org/10.1029/2019GL086124.

Sholkovitz ER, Sedwick PN, Church TM, Baker AR, Powell CF (2012) Fractional solubility of aerosol iron: Synthesis of a global-scale data set. Geochim Cosmochim Acta 89:173-189. https://doi.org/10.1016/j.gca.2012.04.022

Siefert RL, Johansen AM, Hoffmann MR (1999) Chemical characterization of ambient aerosol collected during the southwest monsoon and intermonsoon seasons over the Arabian Sea: Labile-Fe(II) and other trace metals. J Geophys Res 104D 3511-3526. https://doi.org/10.1029/1998JD100067

Strzelec M, Proemse BC, Gault-Ringold M, Boyd PW, Perron MMG, Schofield R, Ryan RG, Ristovski ZD, Alroe J, Humphries RS, Keywood MD, Ward J, Bowie AR (2020) Atmospheric trace metal deposition near the Great Barrier Reef, Australia. Atmosphere 11:390. https://doi.org/10.3390/ atmos 11040390 
Tagliabue A, Bowie AR, Boyd PW, Buck KM, Johnson KS, Saito MA (2017) The integral role of iron in ocean biogeochemistry. Nature 543:51-59. https://doi. org/10.1038/nature21058

Trapp JM, Millero F, Prospero JM (2010) Trends in the solubility of iron in dust dominated aerosols in the equatorial Atlantic trade winds: importance of iron speciation and sources. Geochem Geophys Geosyst 11:Q03014. https://doi.org/10.1029/2009GC00265

van der Werf GR, Randerson JT, Giglio L, van Leeuwen TT, Chen Y, Rogers BM, Mu M, van Marle MJE, Morton DC, Collatz GJ, Yokelson RJ, Kasibhatla PS (2017) Global fire emissions estimates during 1997-2016. Earth Syst Sci Data 9: 697-720. https://doi.org/https://doi.org/10.5194/essd-9-697-2017.

Wagener T, Guieu C, Losno R, Bonnet S, Mahowald NM (2008) Revisiting atmospheric dust export to the Southern Hemisphere ocean Biogeochemical implications. Global Biogeochem Cy 22. https://doi.org/10.1029/ 2007GB002984

Winton VH, Bowie AR, Edwards R, Keywood M, Townsend AT, van der Merwe P, Bollhöfer A (2015) Fractional iron solubility of atmospheric iron inputs to the Southern Ocean. Mar Chem 177:20-32. https://doi.org/10.1016/j.marchem. 2015.06.006

Winton VH, Edwards R, Bowie AR, Keywood M, Williams AG, Chambers SD, Selleck PW, Desservettaz M, Mallet MD, Paton-Walsh C (2016) Dry season aerosol iron solubility in tropical northern Australia. Atmos Chem Phys 16:1282912848. https://doi.org/10.5194/acp-16-12829-2016

Zhang S, Penner JE, Torres O (2005) Inverse modeling of biomass burning emissions using Total Ozone Mapping Spectrometer aerosol index for 1997. J Geophys Res 110:D21306. https://doi.org/10.1029/2004JD005738

\section{Publisher's Note}

Springer Nature remains neutral with regard to jurisdictional claims in published maps and institutional affiliations.

\section{Submit your manuscript to a SpringerOpen ${ }^{\circ}$ journal and benefit from:}

- Convenient online submission

- Rigorous peer review

- Open access: articles freely available online

- High visibility within the field

- Retaining the copyright to your article

Submit your next manuscript at $\boldsymbol{\nabla}$ springeropen.com 